\title{
Comparison of two commercial recirculated aquacultural systems and their microbial potential in plant disease suppression
}

\author{
Sammar Khalil ${ }^{1 *}$, Preeti Panda ${ }^{2}$, Farideh Ghadamgahi ${ }^{3}$, AnnaKarin Rosberg $^{1}$ and Ramesh R Vetukuri ${ }^{3}$
}

\begin{abstract}
Background: Aquaponics are food production systems advocated for food security and health. Their sustainability from a nutritional and plant health perspective is, however, a significant challenge. Recirculated aquaculture systems (RAS) form a major part of aquaponic systems, but knowledge about their microbial potential to benefit plant growth and plant health is limited. The current study tested if the diversity and function of microbial communities in two commercial RAS were specific to the fish species used (Tilapia or Clarias) and sampling site (fish tanks and wastewaters), and whether they confer benefits to plants and have in vitro antagonistic potential towards plant pathogens.

Results: Microbial diversity and composition was found to be dependent on fish species and sample site. The Tilapia RAS hosted higher bacterial diversity than the Clarias RAS; but the later hosted higher fungal diversity. Both Tilapia and Clarias RAS hosted bacterial and fungal communities that promoted plant growth, inhibited plant pathogens and encouraged biodegradation. The production of extracellular enzymes, related to nutrient availability and pathogen control, by bacterial strains isolated from the Tilapia and Clarias systems, makes them a promising tool in aquaponics and in their system design.
\end{abstract}

Conclusions: This study explored the microbial diversity and potential of the commercial RAS with either Tilapia or Clarias as a tool to benefit the aquaponic system with respect to plant growth promotion and control of plant diseases.

Keywords: Aquaponics, Tilapia, Clarias, Pseudomonas flourescens, Pseudomonas veronii, plant growth promotion, in vitro antagonistic

\section{Background}

Major challenges such as climate changes, population increases, limited availability of natural resources, and pandemics threaten food security [1], raising urgent needs to shift to robust and sustainable food production systems [2,3]. As one of the largest food industries globally for animal protein production, aquaculture could play a major role in meeting these needs. Its future

\footnotetext{
* Correspondence: sammar.khali|@slu.se

'Department of Biosystems and Technology, Swedish University of Agricultural Sciences, Box 103, 23053 Alnarp, Sweden

Full list of author information is available at the end of the article
}

expansion will largely rely on land-based recirculated aquaculture systems (RAS), which enable better control of rearing conditions with significantly lower water consumption and release of nutrients (organic matter, nitrogen and phosphorous) into lakes, rivers and the sea [4]. However, accumulation of nitrates (which is harmful to fish) under RAS conditions is problematic [5]. This can be ameliorated by plant uptake, so a potential solution is to integrate RAS and hydroponic systems for plant cultivation in 'aquaponic systems'. Thus, aquaponic systems are promising future food production systems with robust environmental profiles and potential to enhance 
food security. However, their sustainability needs further improvement, as they are complex and more knowledge is needed concerning ideal plant nutrient balances in relation to amounts and types of fish feed, system design, and resilience towards pathogen attack and spread of diseases [6]. These aspects are strongly related to RAS conditions. For example, the lack or low availability of elements in fish feed required for plant growth - such as phosphorous and iron - frequently limits aquaponic systems' productive efficiency [7]. Hence, these nutrients are currently maintained at required levels by adding extra phosphorus and iron to the systems. Stabilization of the RAS element of aquaponic systems, in terms of water quality parameters such as temperature and $\mathrm{pH}$, is also crucial to meet fish, plant and microbial requirements optimally $[8,9]$ and thereby promote good plant and fish growth.

Nevertheless, sustainable approaches for controlling fish, human and plant pathogens in aquaponic systems are also needed [6]. Plant root diseases caused by fungal pathogens such as Fusarium, Verticllium, oomycetes such as Pythium and Phytophthora spp., or bacterial pathogens such as Ralstonia and Xanthomonas spp. are commonly found in aquatic environments including hydroponic systems and hence aquaponic systems [1013]. Biotic and abiotic means to control these pathogens in hydroponic systems, including exploitation of natural microbial communities' suppressive potential, have been investigated [14-19]. However, further study of the suppressive potential of natural microbial communities in aquaponic systems is needed. This is due to the complexity of the systems and associated variables related to water quality, fish feed, the fish, plants and microbial taxa present in compartments from the biofilter to the hydroponic unit (in and through which pathogens may enter and excessively grow if not controlled). Restrictions governing pesticides and antibiotics to control plant and fish diseases, respectively, highlight the need to provide solutions that enhance the sustainability of aquaponic systems towards pathogen attack.

Microbes can suppress pathogens in various ways, including competition, production of antibiotics and extracellular enzymes, and induction of plant resistance or growth-promotion [20]. Microbial communities also have confirmed roles in nutrient recycling [21], plant growth promotion [22], and protection against pathogen attack [23] in aquaponic systems. Hence, the potential utility of modulating the microbial habitat and community in the RAS component of aquaponic systems to counter fish diseases has been addressed [24].

However, more research into microbes' roles and activities in RAS is needed to optimize their promotion of plant growth and suppression of plant diseases. Thus, the objective of the study presented here was to elucidate microbial diversity in a commercial RAS (with no aquaponic connection) and its potential to promote plant growth and act against plant pathogens. For these purposes, variations in the microbial community between systems with two fish species, Tilapia (Oreochromis niloticus) or Clarias (Clarias gariepinus), and between two sampling sites: the water tank with fish biosolids and wastewater have been examined in the current study. The communities' functional roles in terms of production of extracellular enzymes with known activities against plant pathogens and in nutrient solubilization were also examined. The study is based on the following hypotheses. First, a RAS (with no aquaponic connection) hosts microbial communities that are beneficial to plants and antagonistic to pathogens, with characteristics that depend on the fish species used and sampling site in the system. Second, the production of extracellular enzymes and antagonistic potential to control plant pathogens in vitro are fish species- and site-specific.

\section{Results \\ RAS conditions}

Conditions at the sample collection time in the two types of RAS, recirculated aquaculture system, with different fish species were similar in terms of water quality parameters such as $\mathrm{pH}$, temperature, conductivity and contents of both ammonium and nitrate (Table 1). However, the total weight of Tilapia per tank was far lower than the corresponding weight of Clarias (ca. 50 and $160 \mathrm{~kg}$, respectively, at the sampling time). Both species were fed with the same commercial feed, supplied by Skrettting (https://www.skretting.com/en/), but with a slight difference in composition and larger differences in daily amounts. Tilapia were fed five times per day and Clarias 18 times per day.

\section{Microbial abundance}

Microbial enumeration on selective media indicated more general bacterial flora and Pseudomonas

Table 1 Growth conditions in each recirculated aquaculture system (RAS) populated with either Tilapia or Clarias

\begin{tabular}{lll}
\hline Cultivation factors & RAS with Tilapia & RAS with Clarias \\
\hline Temperature & $21{ }^{0} \mathrm{C}$ & $20.9^{0} \mathrm{C}$ \\
$\mathrm{pH}$ & 7.7 & 8.5 \\
Conductivity** & $130 \mathrm{mS} \mathrm{cm}{ }^{-1}$ & $180 \mathrm{mS} \mathrm{cm}$ \\
Ammonium content & $2.1 \mathrm{mg} /$ liter & $1.8 \mathrm{mg} / \mathrm{liter}$ \\
Nitrate content & $280 \mathrm{mg} /$ liter & $188 \mathrm{mg} /$ liter \\
Nitrite content & $0,59 \mathrm{mg} /$ liter & $0,18 \mathrm{mg} /$ liter \\
Fish weight & $40-600 \mathrm{~g}$ per tank & $100-4000 \mathrm{~g}$ per tank \\
Feed composition & $37 \%$ protein $+10 \%$ fat & $44 \%$ protein $+12 \%$ fat \\
Daily amount & 5 times & 18 times \\
\hline
\end{tabular}

** Electrical conductivity 
fluorescens in samples collected from the Tilapia RAS system than the Clarias RAS system (Fig. 1). However, there were differences in amounts of general fungal flora, which were more abundant in samples of Clarias wastewater than in Clarias water tank samples or either type of Tilapia RAS samples.

\section{Diversity of the microbial communities}

Processing Ilumina MiSeq sequencing data revealed the presence of 4,558 bacteria operational taxonomic units (OTUs) and 405 fungal OTUs in samples of the two RAS. Total read counts for the bacterial and fungal datasets were 647, 232 and 530,351, respectively. The bacterial communities had significantly higher alpha diversity (according to Shannon indices) in Tilapia RAS water tank samples $(\mathrm{p}=0.021)$ than in Clarias RAS water tank samples (Fig. 2a). However, bacterial alpha diversity did not significantly differ $(p<0.05)$ between Tilapia RAS samples (water or waste) and Clarias RAS wastewater samples. Calculated Chao1 indices also indicated that alpha diversity was significantly higher $(\mathrm{p}=0.012)$ in samples of Tilapia RAS wastewater than in Clarias RAS water tank samples, which had the lowest Chaol indices (Fig. 2b). In further accordance with the Shannon indices, Chao1 indices did not significantly differ between Tilapia RAS samples (tank or wastewater) and Clarias RAS wastewater samples.

Regarding abundance of Pseudomonas, no significant differences $(\mathrm{p}<0.05)$ in log-transformed Pseudomonas counts between the four types of samples (Tilapia and Clarias RAS tank water and wastewater) were found, as shown in Fig. 3. However, although we found no significant differences between treatments in fungal community alpha diversity in terms of Shannon indices $(\mathrm{p}=0.211)$ (Fig. 4a), there were highly significant differences in Chao1 indices $(p=0.008)$ between treatments. More specifically, they clearly indicated that fungal diversity was higher in the Clarias RAS wastewater than in the Tilapia RAS water tank, although Chao 1 indices did not significantly differ between any other pairs of sample types (Fig. 4b).

Dendrogram analyses demonstrated that the bacterial and fungal communities also differed between the Tilapia and Claria cultivation systems (Fig. 5), inter alia in the bacterial communities in the water tank and wastewater of the Tilapia RAS (Fig. 5a). However, samples of these communities also shared similarities in their bacterial communities. Fungal communities in Tilapia water tank and waste samples also differed (Fig. 5b). By contrast, there was no clear difference between samples of the Clarias RAS in terms of either bacterial or fungal communities.

The beta diversity metrics clearly distinguished the bacterial (Fig. 6) and fungal (Fig. 7) communities associated with the Tilapia and Clarias RAS, and sampling sites in the two systems. The RAS with the two fish species were clearly separated along the first axis of the generated Principal Coordinate Analysis (PCoA) plot (Fig. 6a) and sampling sites (more prominently for samples from the Tilapia RAS than the Clarias RAS) along the second axis (Fig. 6b). No significant differences between sampling site in this respect in the Clarias system were detected. Similar patterns in diversity of fungal communities were also detected (Fig. 7).

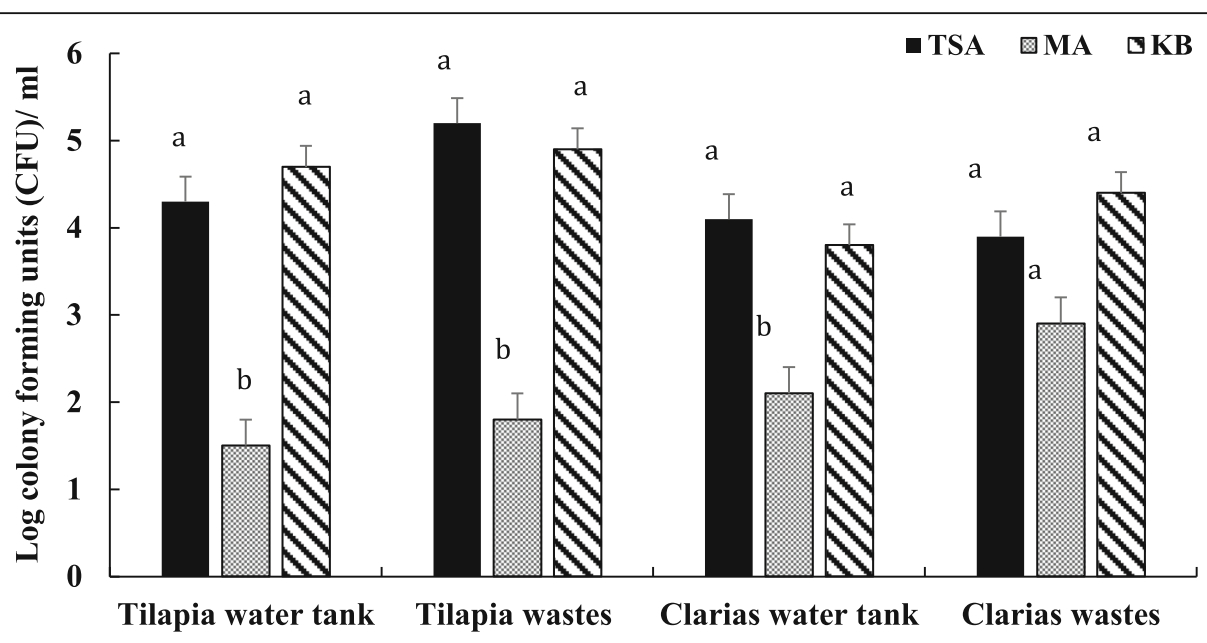

Treatments

Fig. 1 Microbial colonies isolated from water and waste samples from Tilapia and Clarias RAS and enumerated on $0.1 \%$ Tryptic soya agar (TSA) complemented with cycloheximide $\left(100 \mu \mathrm{L} \mathrm{mL}^{-1}\right)$ for enumeration of the general bacterial flora; $0.5 \%$ malt extract agar (MA) for enumeration of the general fungal flora; and on King Agar B (KB) with cycloheximide $\left(100 \mu \mathrm{g} \mathrm{mL}^{-1}\right)$ for enumeration of fluorescent pseudomonads. Letters above the bars indicate the significant differences between the treatments 


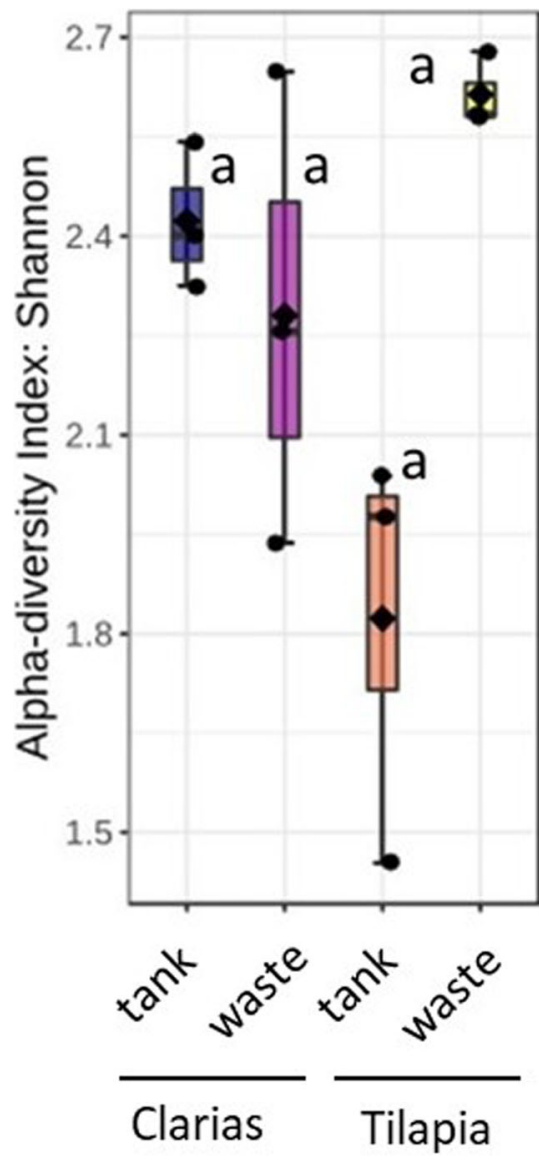

(a)

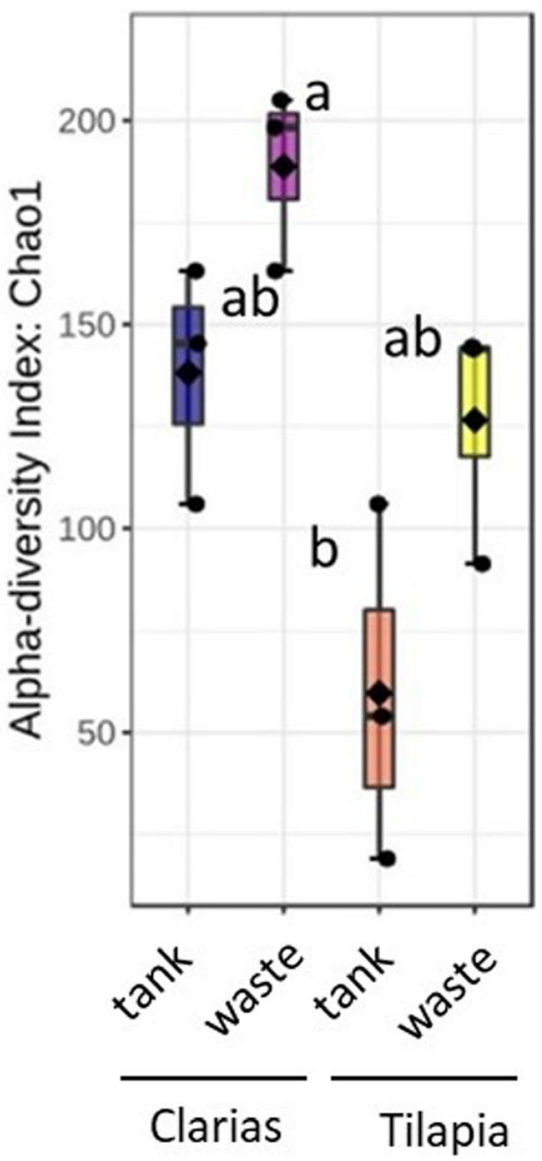

(b)

Fig. 2 Alpha diversity of bacterial communities in the fish water tank and the waste water sampling sites of the Tilapia and Clarias RAS as judged by the diversity indices (a) Shannon and (b) Chao1. Letters above the boxplots indicate the significant differences between the treatments

Analyses of the relative abundance of the bacterial communities showed that the phylum Fusobacteria dominated in samples of Tilapia RAS wastewater, followed by Bacteroidetes and Proteobacteria (accounting for 50, 30 and $20 \%$ of total bacterial OTUs, respectively) (Fig. 8). Tilapia water tank samples were dominated by the phylum Proteobacteria $(60 \%)$ followed by Bacteroidetes $(20 \%)$, Fusobacteria and Actinobacteria (10\%). Actinobacteria and Proteobacteria dominated in samples of the Clarias RAS. Actinobacteria were more dominant in the water tank $(75 \%)$ than the waste samples $(60 \%)$. In the Clarias RAS, Bacteroidetes and Fusobacteria were more dominant in the wastewater than in water tank samples. However, in the Tilapia system Actinobacteria were either less abundant than in the Clarias RAS, or completely absent.

The bacterial genera Microbacterium, Cetobacterium and Chrysobacterium dominated in samples from the Clarias system (Fig. 9). Microbacterium was the most abundant genus in both water tank and waste samples.
Tilapia waste samples were dominated by the genera Cetobacterium and Flavobacterium, followed by Chryseobacterium, Pseudomonas and Bacteroides. Samples from the Tilapia RAS water tank included more genera and were dominated by Janthinobacterium, Flavobacterium, Chryseobacterium, Pseudomonas, Pseudorhodobacter, Bacteroides, Sorangium and Hydrotalea.

As indicated by the heatmap in Fig. 10, the genera Sorangium, Pseudomonas, Pseudorhodobacter, Acinetobacter, Simplicispira, Rhodococcus, Pedobacter, Rhodobacter, Undibacterium, Hydrogenobacter, Phenyloacterium, Alpinimonas, Acidovorax, Paucibacter, Legionella, Leisona, Duganella were notably present in Tilapia RAS tank water. Wastewater in this system included the genera Janthinobacterium, Cetobacterium, Pseudomonas, Aremonas, Arcobacterium, Clostridium, Paludibacter, Sulfurospirium, Dechloromonas, Arcobacter, Propionivibrio, Limnohabitans, Paludibacter and Macellibacteroides. The genera Chryseobacterium, Cetobacterium, Simplicispiria, Thermomonas, Rhodanobacter, Ottowia, 


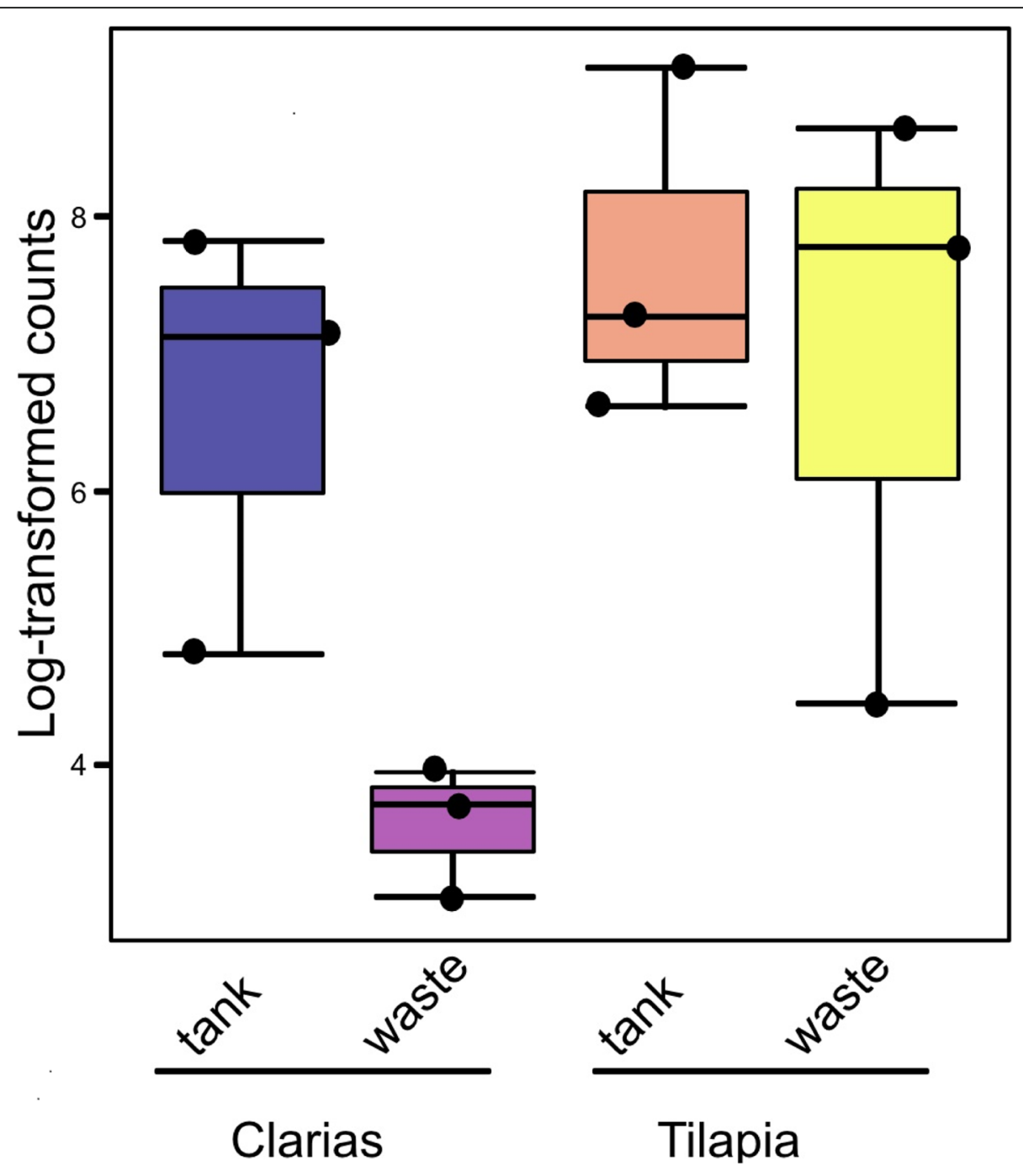

Fig. 3 Log-transformed counts of Pseudomonas communities in the water tank and wastewater site from the Tilapia and Clarias RAS. Letters above the boxplots indicate the significant differences between the treatments

Bergeyella, Prevotella and Clostridium were present in Clarias RAS wastewater. The genera Chryseobacterium, Microbacterium, Macellibacteroides and Azospirillum were predominant in Clarias water tank samples.

Analyses of the relative abundance of the fungal communities also revealed differences in the dominant taxa depending on the fish species and sampling site (Fig. 11). Most (> $70 \%$ ) of the fungal OTUs were unclassified in samples from the Tilapia cultivation system (either water tank or wastewater). However, the phylum Ascomycota was more abundant in samples from the Tilapia water tanks than in samples of Tilapia RAS wastewater, in which the phylum Basidiomycota was more abundant.

There were fewer unclassified fungal OTUs in samples from Clarias RAS water tanks and wastewater than in the Tilapia RAS samples. However, their relative abundances differed between Clarias water tank and waste samples. The waste samples were highly dominated by the phyla Ascomycota, Basidiomycota and unclassified phyla of the kingdom Protista. Water samples from the Clarias system contained Basidiomycota and Ascomycota, but were dominated by an unclassified member of the kingdom Protista (Fig. 11).

Unclassified fungi also dominated at the genus level (70\%) in Tilapia and Clarias RAS (Fig. 12). However, Trichosporon spp. were abundant in Clarias RAS tank and wastewater (accounting for $25 \%$ of the total fungal OTUs), and Tilapia RAS wastewater. The genus Yarrowia was exclusively found in a Tilapia water tank, while the genus Trichomonascus was only detected in the Clarias system.

The fungal communities' heatmap showed that members of the phylum Basidiomycota in Clarias water tank samples included the genera Trichosporon, Trichomanoascus, Phodotonula, Malassezia, Mortierella, 


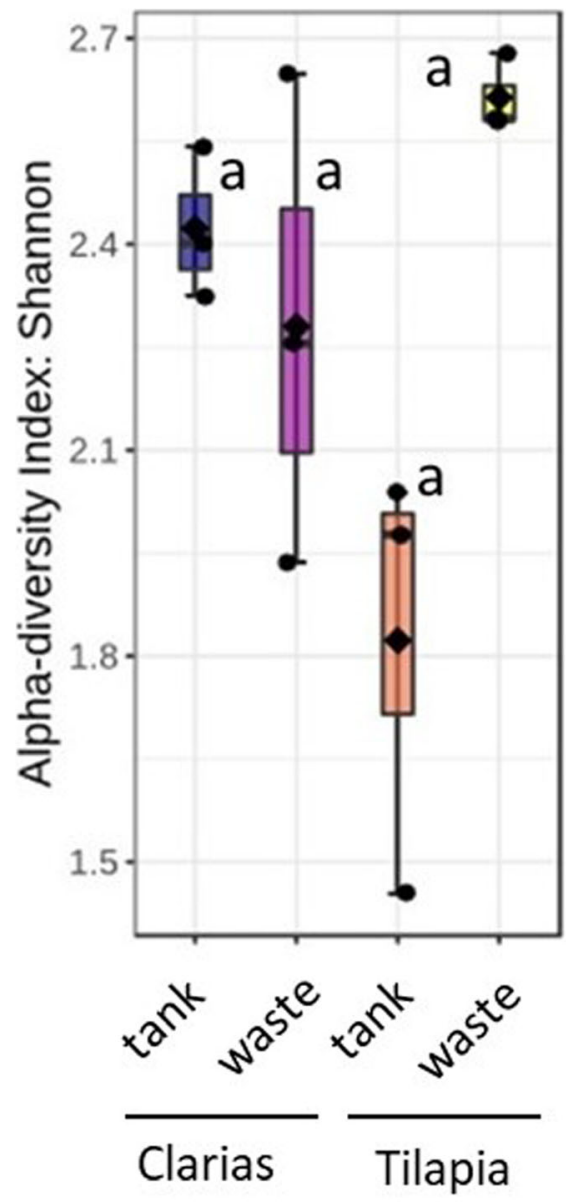

(a)

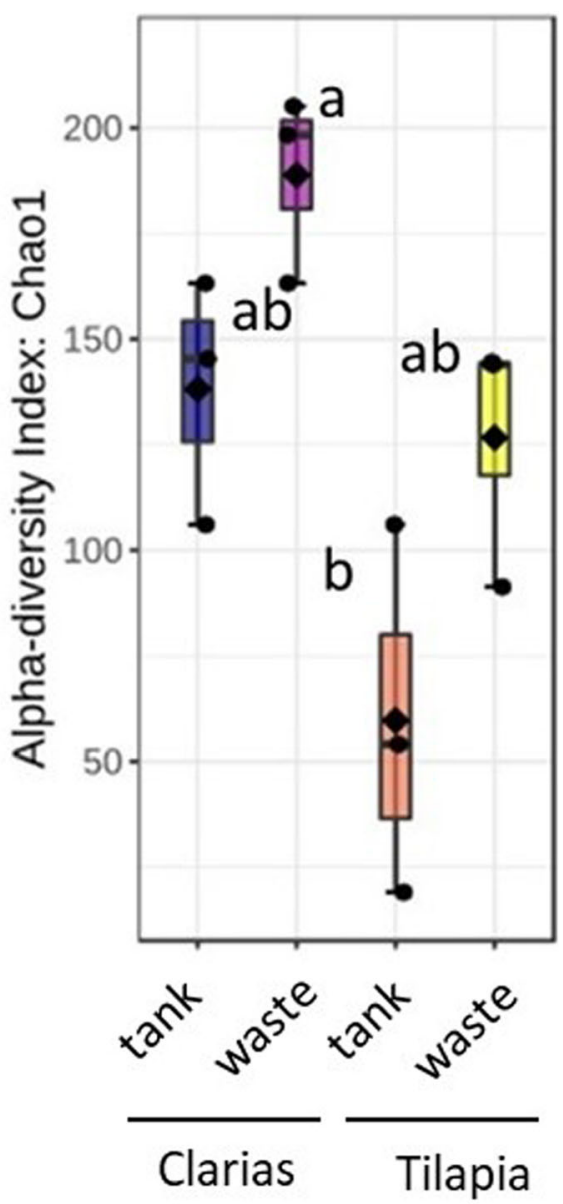

(b)

Fig. 4 Alpha diversity of fungal communities from the water tank and the fish waste sample sites in the recirculated aquaculture systems populated with two different fish species -Tilapia or Clarias, as judged by the diversity indices (a) Shannon and (b) Chao1. Letters above the boxplots indicate the significant differences between the treatments

Ascochyta, Mucor, Cladosporium, Wallemia, Trichoderma, Fusarium and Deharyomyces (Fig. 13). The genera Aspergillus, Debaryomyces, Wallemia, Sterigmatomyces, Exobasidium, Trichosporon and Pleospora were found in Clarias RAS waste water. The Tilapia RAS waste water contained more genera than Tilapia water tank samples and was dominated by the genera Candida, Trichosporon, Bettsia, Sporobolomyces, Penicillium, Entomocariticium, Cryptococcus, Preussia, Macrophomina, Sterigmatomyces, Microascuss and Enyodonium. Dominant genera in the Tilapia water tank samples included Yarrowia, Acremonium, Harposporium, Aureobasidium and Phaeoacremonium.

\section{Identification of pure cultures and their enzyme activity potential}

In total, nine isolates were collected and identified as described in Table 2. Pseudomonas fluorescens was the most abundant isolate identified in Clarias RAS wastewater, and both Tilapia RAS water tanks and wastewater. Pseudomonas veronii was identified in Tilapia RAS wastewater, and both Pseudomonas veronii and Variovorax paradoxus strains in Tilapia RAS wastewater.

Regarding enzyme activities, some of the strains isolated from both Tilapias and Clarias RAS waste samples clearly released cellulases (Table 2). Bacterial strains identified in the Clarias system's wastewater also produced proteases and phosphatases. All the strains isolated from Tilapia RAS wastewater had amylase activities, but not all of them had protease and phosphatase activities. Strains isolated from Tilapia tanks clearly released proteases and phosphatases and one showed amylase activity. Further, most of the strains isolated from Clarias RAS wastewater, and some isolated from Tilapia RAS (water tank and waste) samples clearly released siderophores. 


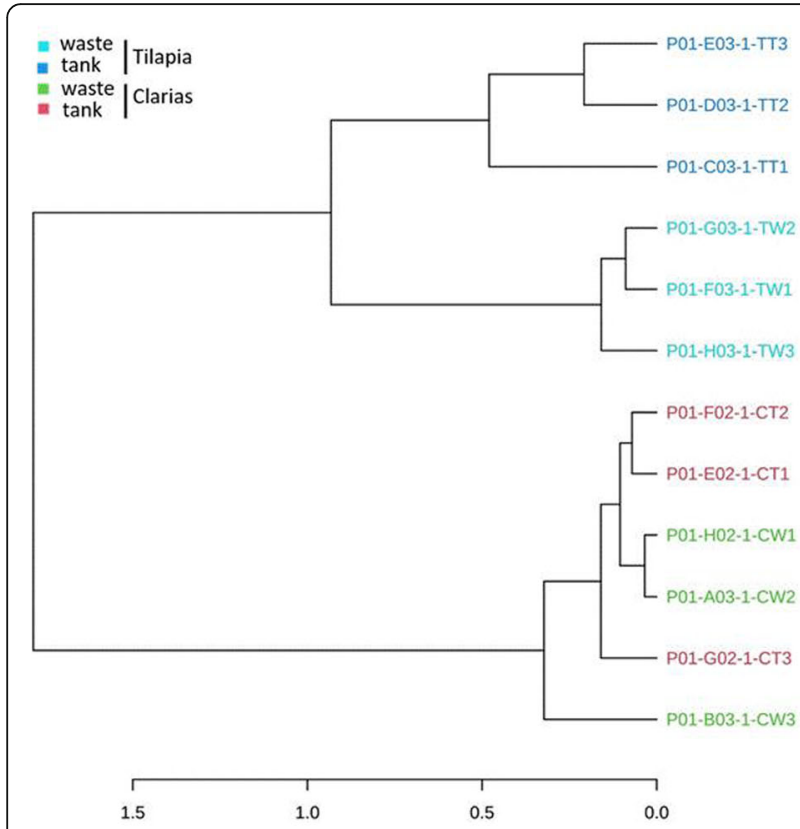

(a)

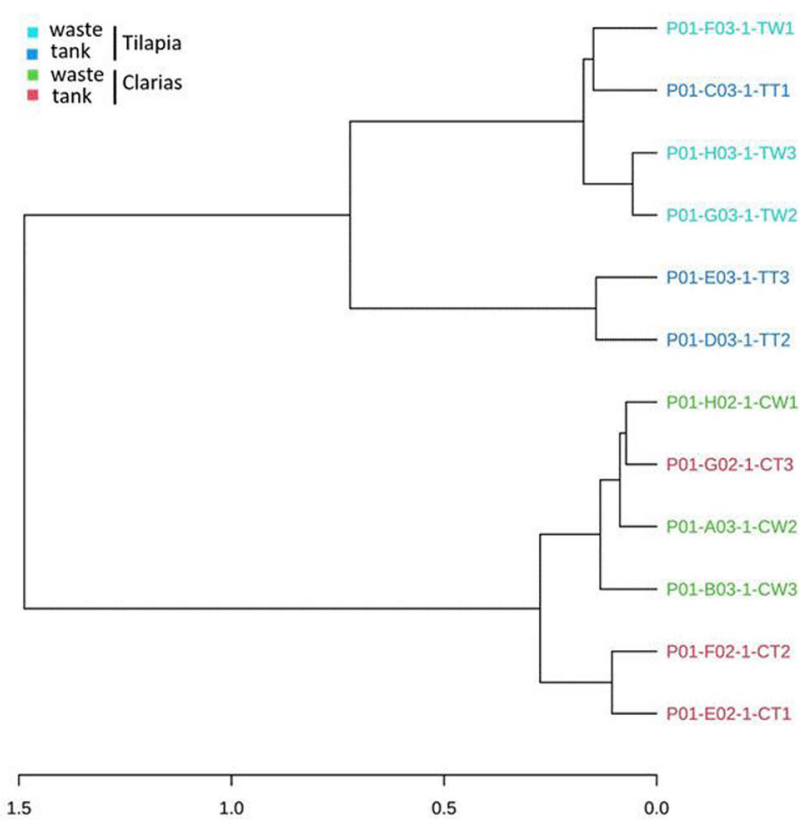

(b)

Fig. 5 The dendrogram analyses of (a) bacterial and (b) fungal communities in samples collected from the RAS populated with either Tilapia or Clarias. The samples were collected from the Tilapia water tank (TT), Tilapia waste (TW), Clarias water tank (CT), and Clarias waste (CW)

\section{In vitro antagonistic activity of bacterial isolates against plant pathogens}

In vitro tests clearly showed that some of the isolated strains were antagonistic towards the plant pathogens Phytophthora cactorum and Verticillium dahliae (Fig. 14). Isolate 6 (Pseudomonas fluorescens) from Clarias water tank samples showed the highest antagonistic potential against both $P$. cactorum and $V$. dahliae. However, $P$. fluorescens (Isolate 6) had higher activity against $V$. dahliae than P. cactorum. Apart from P. fluorescens Isolate 6, Isolates 3 (P. fluorescens) and 4 (Pseudomonas veronii) from Tilapia RAS waste had the highest antagonistic activities towards $P$. cactorum and $V$. dahliae. Isolates 2 (Pseudomonas fluorescens) from Tilapia water tank and 8

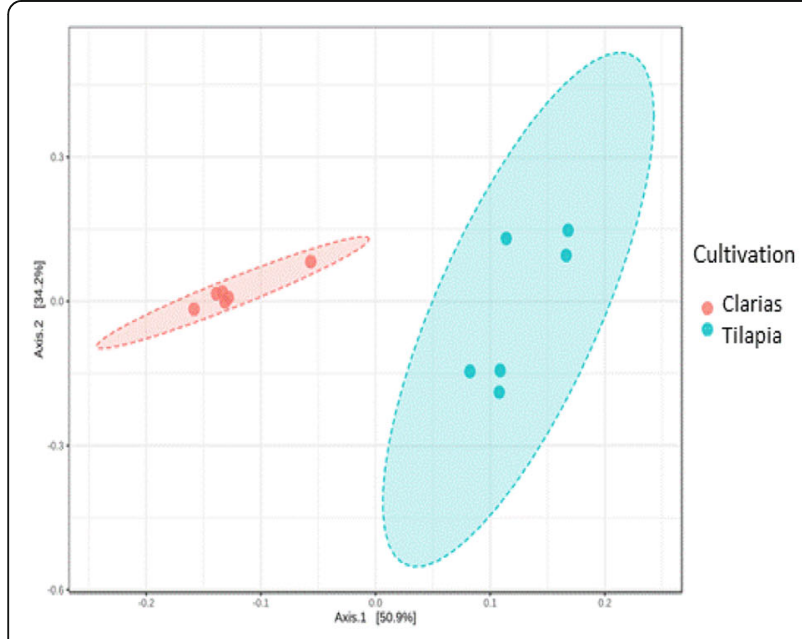

(a)

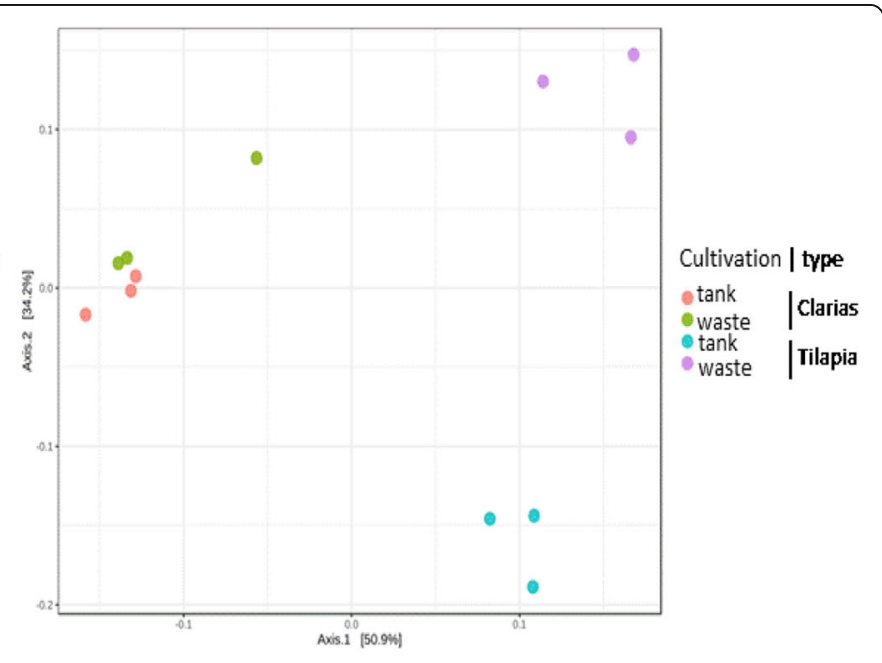

(b)

Fig. 6 PCOA plots on beta diversity of the bacterial communities distinguished by (a) the cultivation system (ANOSIM; $R=0.92$ and $p<0.003$ ) or (b) sampling site (ANOSIM; $R=0.81$ and $p<0.001$ ) in the system using Tilapia or Clarias as fish species 


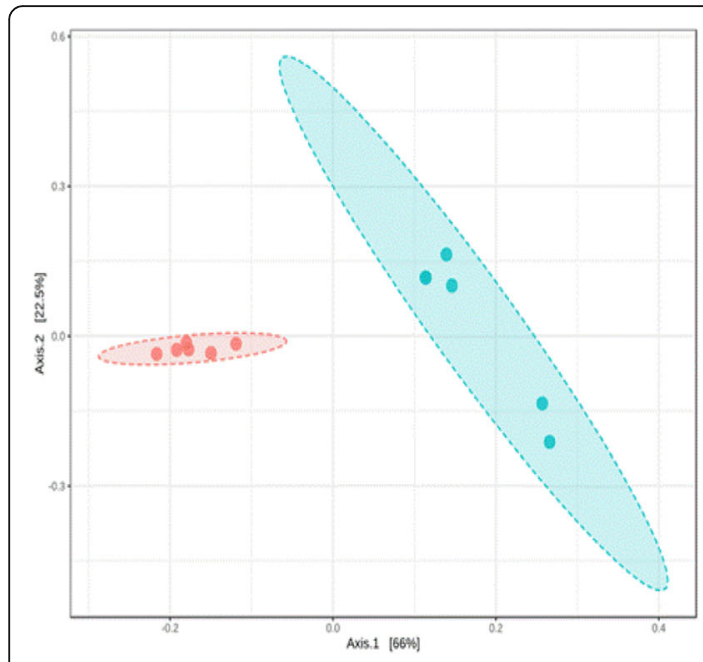

(a)

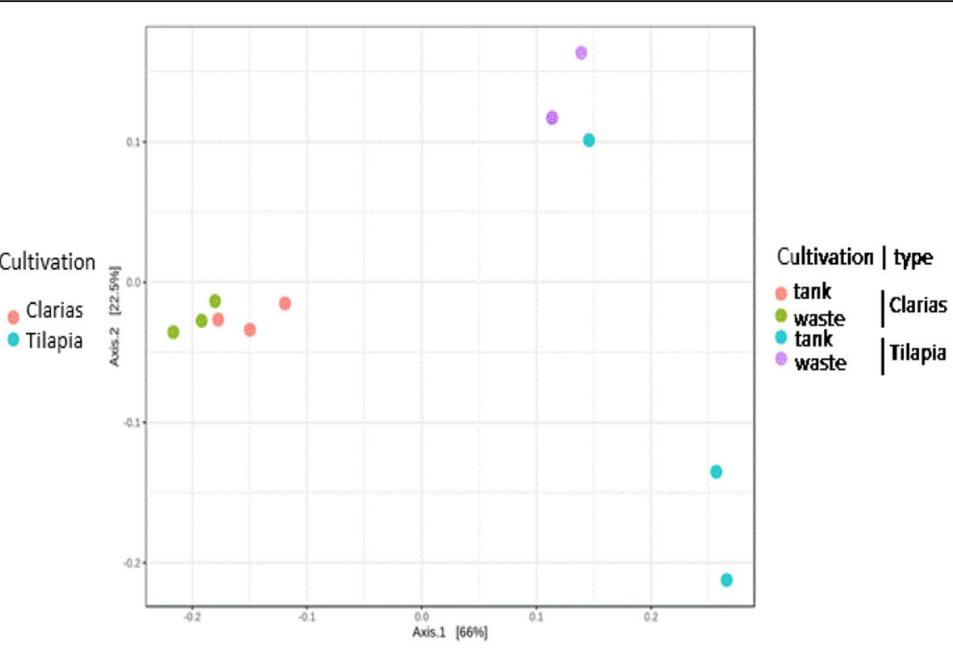

(b)

Fig. 7 PCoA plots on beta diversity of the fungal communities distinguished by (a) the cultivation system (ANOSIM; $R=0.05$ and $p<0.003$ ) or (b) sampling site (ANOSIM; $R=0.81$ and $p<0.001$ ) in the system using Tilapia or Clarias as fish species

(Pseudomonas fluorescens) from Clarias RAS wastewater had higher antagonistic activities towards $V$. dahliae than P. cactorum. By contrast, Isolate 5 (Variovorax paradoxus) from Tilapia RAS wastewater was more antagonistic towards $P$. cactorum than $V$. dahliae.

\section{Detached leaf assays}

Two of the best performing bacterial isolates in the pathogen antagonism tests, $P$. veronii (Isolate 4 ) and $P$. fluorescens (Isolate 6), were tested for their potential to control P. cactorum in detached leaf assays. For this,

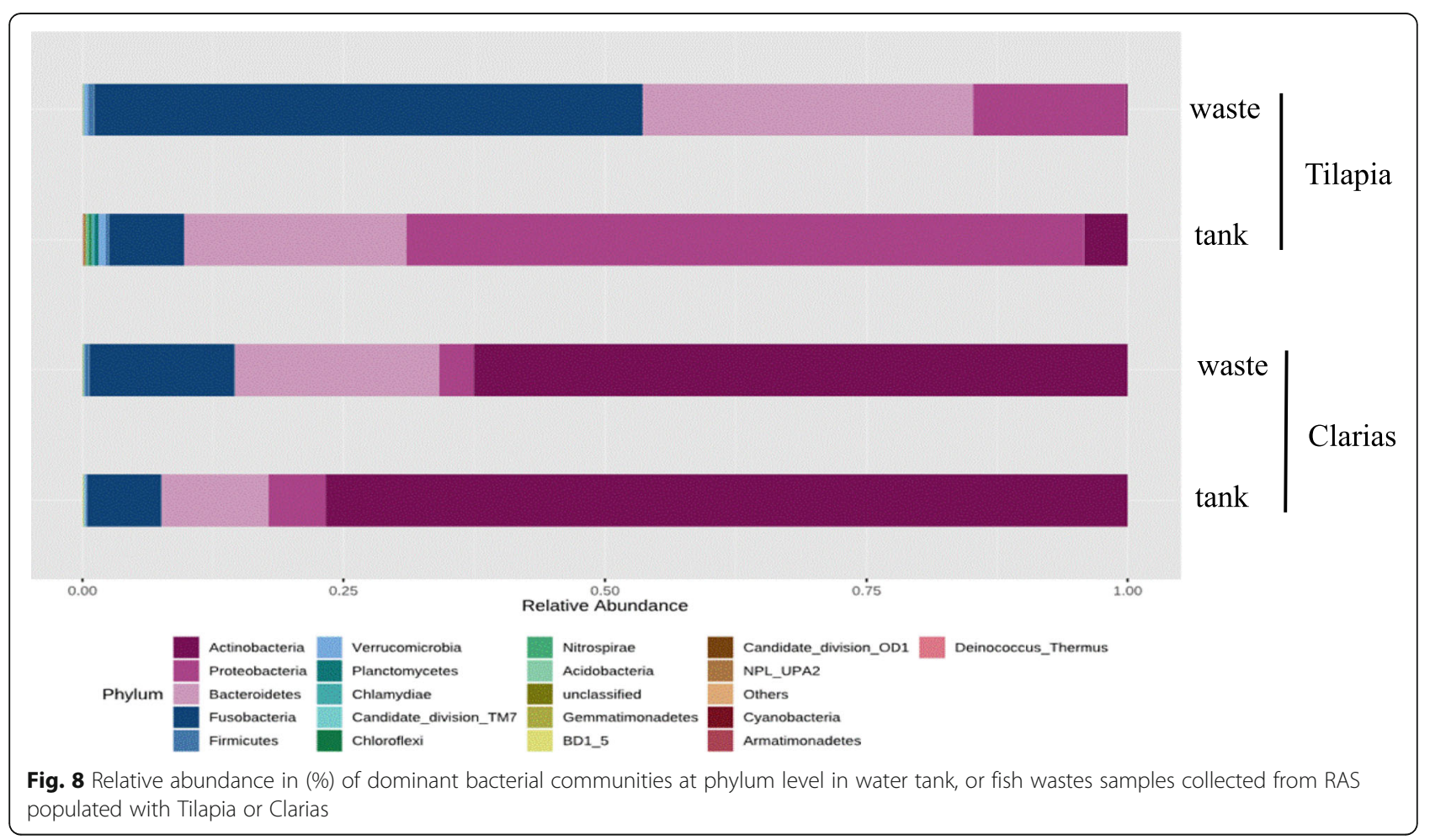



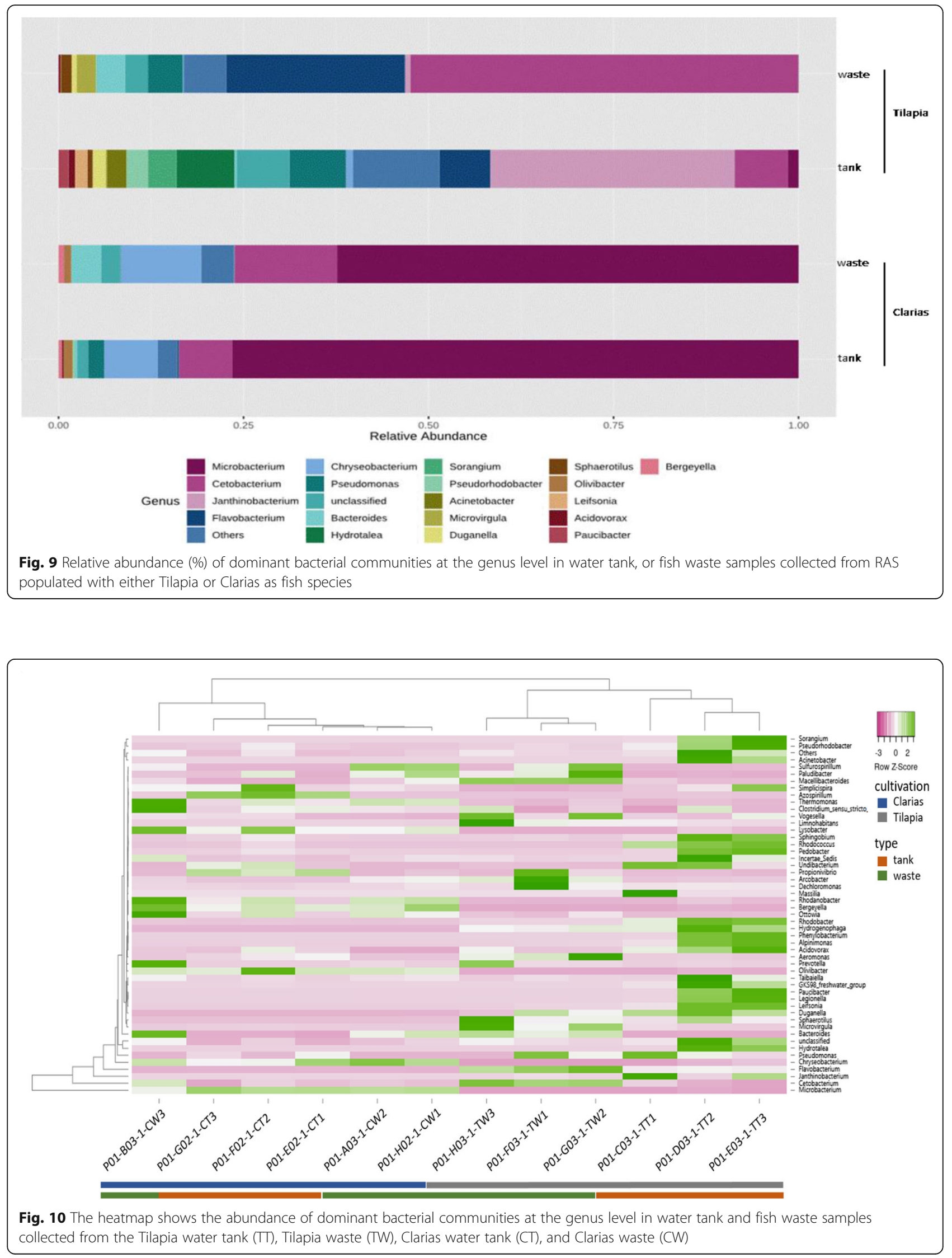


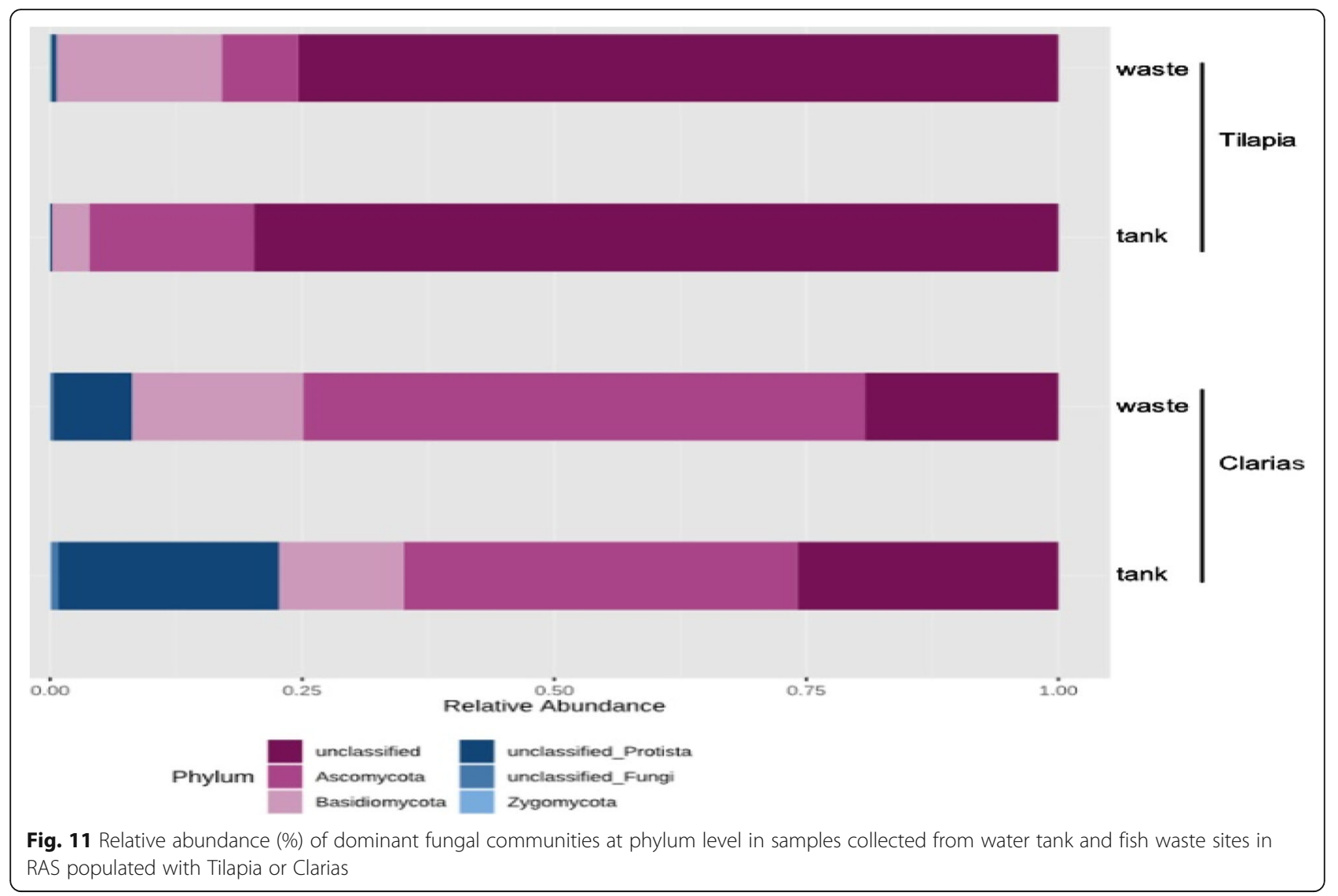

strawberry (Fragaria $\times$ ananassa $\mathrm{cv}$. Sonata) leaves were inoculated with $P$. cactorum, and started showing symptoms of infection four days later, while controls inoculated with sterile distilled water remained symptomless. These results confirmed the viability of the zoospore suspensions and absence of the pathogen on uninoculated leaflets. Furthermore, treatment with Isolate 6 ( $P$. fluorescens) together with $P$. cactorum showed potent disease inhibition. However, Isolate $4(P$. veronii) was less effective for controlling the progression of disease caused by $P$. cactorum (Fig. 15).

\section{Discussion}

Our study provides novel insights into the diversity of microbial communities in commercial RAS, their beneficial effects on plants, and antagonistic potential against plant pathogens. We found that microbial diversity varied depending on the fish species populating the system and sampling point.

The effect of fish species on microbial composition is supported by the beta diversity analyses, which revealed significant differences in the bacterial (Fig. 6) and fungal (Fig. 7) communities of the Tilapia and Clarias RAS.

The fish species in the system had significant effects in the water tank environment, in which the bacterial community was richer in the Tilapia RAS (Fig. 2), but the fungal community was richer in the Clarias RAS (Fig. 4). These findings are consistent with previous indications that the composition of microbial communities is strongly influenced by associated species of fish $[25,26]$. The results also agree with previous observations that fungal diversity was higher in a Clarias system than in a Tilapia system [26].

In both Tilapia and Clarias systems, sampling site had no significant effect on the evenness and richness of either bacterial communities (Fig. 2) or fungal communities (Fig. 4). By contrast, the site effect was evident in the composition of the bacterial (Fig. 6) and the fungal (Fig. 7) communities in the Tilapia RAS. Moreover, the dendrogram analyses (Fig. 5) showed there were clear distinctions between the bacterial and fungal communities associated with the two fish species. Differences associated with sampling sites in the Tilapia RAS were also detected. Microbial diversity in RAS is also a function of the water's physicochemical properties (such as $\mathrm{pH}$ and temperature), the feed, gut microbiome of the fish and nutrient contents [27-29]. In this study the cultivation conditions for both fish species were very similar. However, there were substantial differences in their population density and fish biomass per tank was much lower in the Tilapia RAS than in the Clarias RAS (Table 1). This may have considerably influenced 


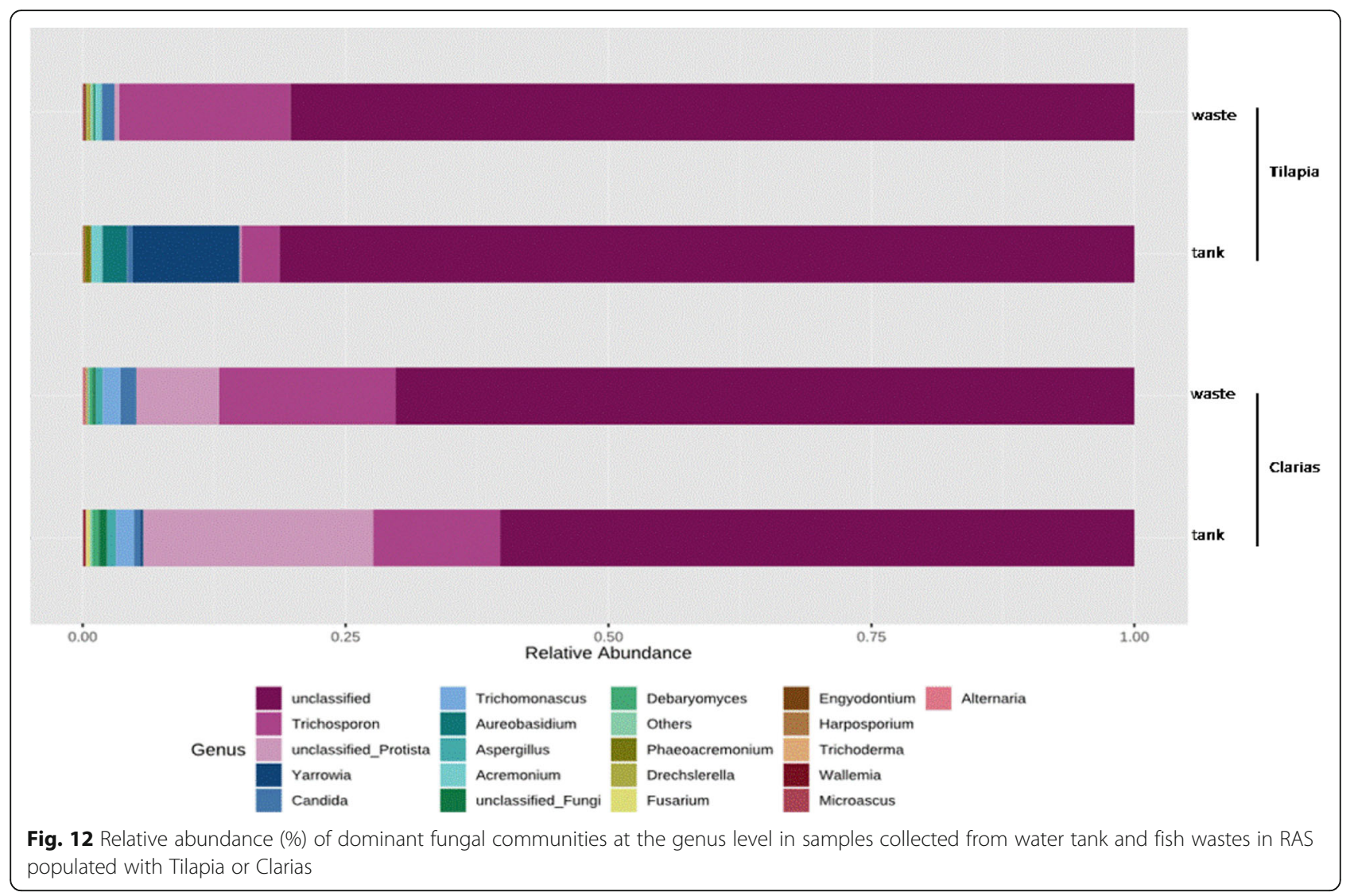

unmeasured variables in the water tanks. Previous studies have indicated that the fish gut microbiome can strongly influence the wastewater microbiome [27], but we detected no such indications as microbial diversity in the water tank and wastewater were very similar in both RAS.

The microbial communities of the Tilapia RAS were dominated by bacteria, including the phyla Fusobacteria, Proteobacteria and Bacteroidetes (Fig. 8). Relative abundances of these phyla in the water tank and waste environment differed, primarily due to the dominance of Proteobacteria in the former and Fusobacteria in the latter (Fig. 8). The identified phyla are common in freshwater systems and have been previously detected in Tilapia systems [27]. Our results are also in line with previous findings that Proteobacteria dominated in biofilms in an aquaculture system [30]. Proteobacteria are characterized as $r$-strategists with an important function in nutrient recycling [31]. Their higher abundance in the Tilapia water tank may have been due to the nutrient conditions in that environment. The high dominance of Fusobacteria in the Tilapia RAS wastewater is consistent with previous indications that the abundance of this genus is related to microbiota in the fish gut, where nutrient breakdown occurs [27]. Our results show that Actinobacteria was the most abundant phylum in the
RAS environment with Clarias (Fig. 8). Actinobacteria have received much recent attention for their potential role as probiotic bacteria in marine and freshwater aquaculture [32, 33], further highlighting the importance of the antimicrobial activities of these beneficial bacteria for fish and plant health.

Furthermore, microbial communities in RAS (with and without an aquaponic connection) and Tilapia rearing tanks have been shown to be rich in bacteria with potential capacity to promote plant growth [22, 34]. Our results are consistent with these findings and highlight the Clarias system's potential to host, in both the tank water and waste water, bacterial genera with plant-growth promoting traits. These include Microbacterium and Cetobacterium (Fig. 9), which are common rhizobacteria known to have beneficial effects on plant growth [22]. The Tilapia system in our study was richer than the Clarias system in the genera Pseudomonas, Cetobacterium, Flavobacterium, Sorangium, Pseudorhodobacter and Bacteroides, which play a prominent role in promoting plant growth and protecting plants against root pathogens [22]. In addition, the Tilapia RAS tank water (Fig. 10) hosted important genera in biodegradation and alleviation of abiotic stress (which are highly relevant in aquaponic cultivation systems), such as Simplicispira, Rhodobacter and Acidovorax [35, 36]. The identified 


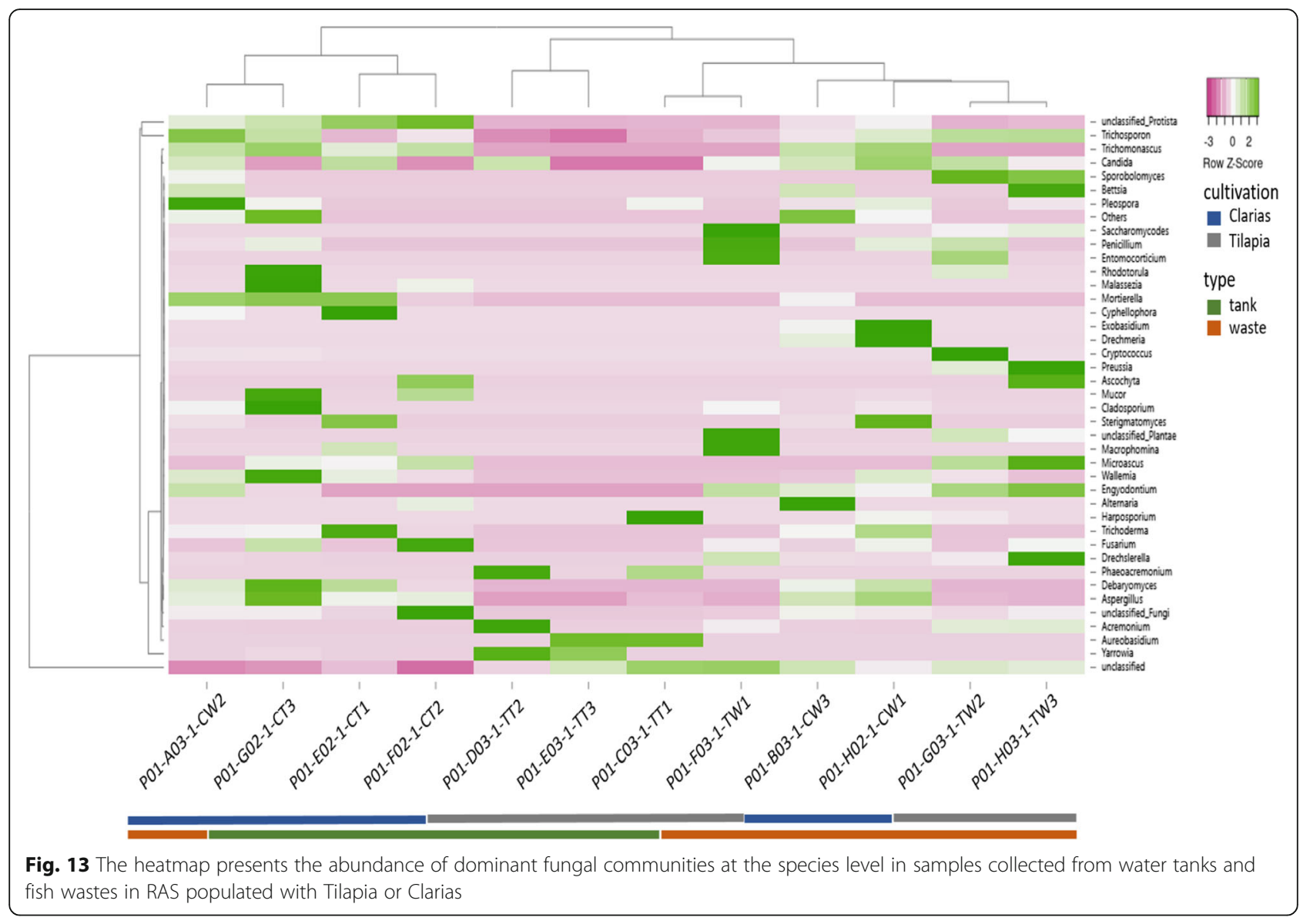

Table 2 Identification and enzyme activities of the pure bacterial isolates isolated from samples collected from water tanks and wastes in RAS populated with Tilapia or Clarias. (+) indicates positive and (-) indicates negative enzyme activities

\begin{tabular}{|c|c|c|c|c|c|c|c|}
\hline $\begin{array}{l}\text { Number of the } \\
\text { isolate }\end{array}$ & Identification & $\begin{array}{l}\text { Collection } \\
\text { site }\end{array}$ & $\begin{array}{l}\text { Amylase } \\
\text { activity }\end{array}$ & $\begin{array}{l}\text { Protease } \\
\text { activity }\end{array}$ & $\begin{array}{l}\text { Phosphatase } \\
\text { activity }\end{array}$ & $\begin{array}{l}\text { Cellulase } \\
\text { activity }\end{array}$ & $\begin{array}{l}\text { Siderophore } \\
\text { production }\end{array}$ \\
\hline 1 & $\begin{array}{l}\text { Pseudomonas } \\
\text { fluorescens }\end{array}$ & $\begin{array}{l}\text { Tilapia water } \\
\text { tank }\end{array}$ & + & + & + & - & + \\
\hline 2 & $\begin{array}{l}\text { Pseudomonas } \\
\text { fluorescens }\end{array}$ & $\begin{array}{l}\text { Tilapia water } \\
\text { tank }\end{array}$ & - & + & + & - & - \\
\hline 3 & $\begin{array}{l}\text { Pseudomonas } \\
\text { fluorescens }\end{array}$ & Tilapia wastes & + & - & + & + & - \\
\hline 4 & $\begin{array}{l}\text { Pseudomonas } \\
\text { veronii }\end{array}$ & Tilapia wastes & + & - & + & + & + \\
\hline 5 & $\begin{array}{l}\text { Variovorax } \\
\text { paradoxus }\end{array}$ & Tilapia wastes & + & - & - & - & - \\
\hline 6 & $\begin{array}{l}\text { Pseudomonas } \\
\text { fluorescens }\end{array}$ & $\begin{array}{l}\text { Clarias water } \\
\text { tank }\end{array}$ & + & + & + & + & + \\
\hline 7 & $\begin{array}{l}\text { Pseudomonas } \\
\text { fluorescens }\end{array}$ & Clarias wastes & - & + & + & + & + \\
\hline 8 & $\begin{array}{l}\text { Pseudomonas } \\
\text { fluorescens }\end{array}$ & Clarias wastes & - & + & + & - & + \\
\hline 9 & Variovorax spp. & Clarias wastes & - & - & - & - & - \\
\hline
\end{tabular}




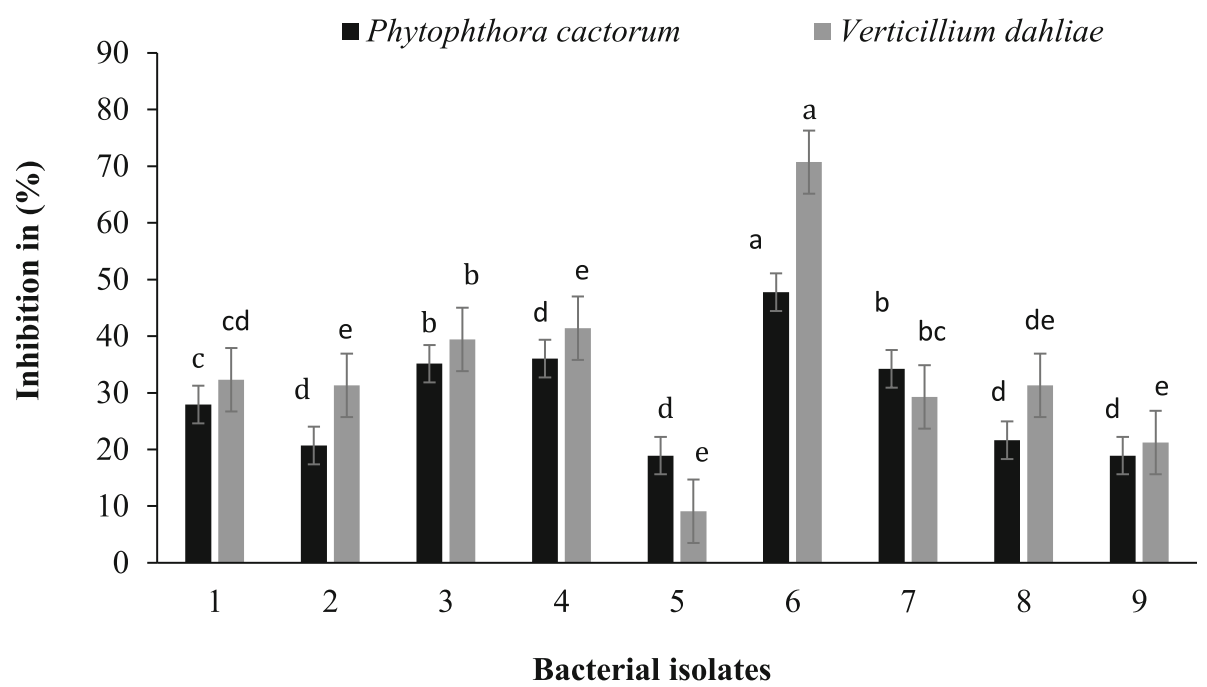

Fig. 14 Inhibition (\%) of radial growth of the plant pathogens Phytophthora cactorum and Verticillium dahliae by the bacterial isolates 1-2 from Tilapia water tanks, isolates 3-5 from Tilapia wastes, isolates 6 from Clarias water tanks and isolates 7-9 from Clarias wastes

genera in Tilapia RAS wastewater (Fig. 10) indicate a shift in bacterial composition between the water tank and waste sampling sites. Genera such as Clostridium, Chryseobacterium, Janthinobacterium, Cetobacterium and Pseudomonas identified in the waste environment also have plant growth-promoting characters [22].
Moreover, the genera Propionivibrio, Sulfurospirium and Dechloromonas are involved in nutrient breakdown, and the removal of certain compounds, e.g., phosphorous by Propionivibrio [37]. Samples from the waste site also included genera involved in biodegradation and alleviation of abiotic stress such as Limnohabitans and Paludibacter

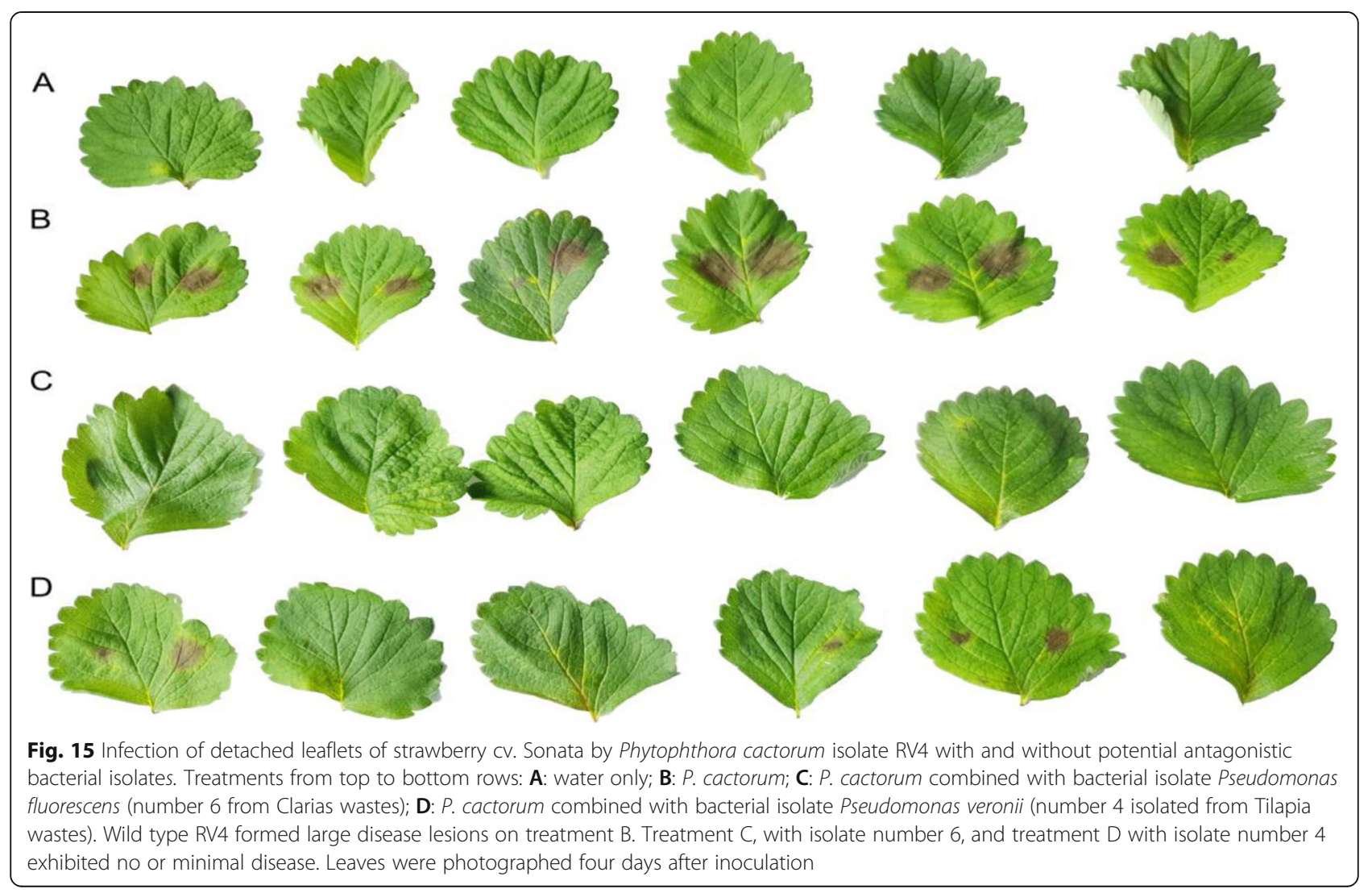


[38]. However, the occurrence of Legionella and Aremonas in Tilapia RAS water tank and wastewater samples requires further investigation as these genera are opportunistic pathogens in aquatic environments and of concern in terms of food safety and human health [39]. On a more positive note, Pseudomonas fluorescens has confirmed efficiency for controlling the pathogen Aremonas [24], and Pseudomonas spp. were detected in both Tilapia and Clarias RAS (Fig. 3). Pseudomonas fluorescens is a rhizobacterium of the genus Pseudomonas, which we identified in samples from both our RAS (Table 2). Optimizing conditions to favor beneficial microbes in a RAS and the root environment in aquaponic systems might thus be an effective strategy to control fish diseases caused by pathogens in aquaponic systems.

Regarding the fungal communities in our sampled RAS, we found that they included genera with known importance as promoters of plant growth and antagonists towards plant pathogens. These genera included: Cladosporium, Mortierella [40] and Trichoderma [41] in Clarias RAS tank water: Pleospora [42] in Clarias RAS waste water; Acremonium [43] in Tilapia RAS tank water and Penicillium [40] in Tilapia wastewater samples (Figs. 12 and 13). However, these systems also contained potentially pathogenic genera for humans and plants, such as Fusarium [43], Candida and Cryptococcus, which pose significant challenges that need further investigation. Further investigation of fungal sequences and appropriate primers is also needed to enable identification of fungi that could not be classified beyond the level of phylum or genus in this study.

The bacterial strains isolated from the Tilapia system showed clear potential to inhibit development of symptoms of disease caused by two well-known plant pathogens and hence as biocontrol agents in aquaponic systems. The only isolated bacterial strain that showed such potential and was positively identified and present in all samples was Pseudomonas fluorescens. However, log transformation of the Pseudomonas data we obtained indicates that the other strains were also present in all the investigated samples (Fig. 3), thus strengthening our findings concerning the isolated strains. Other less ubiquitous taxa were Pseudomonas veronii and Vaiovorax paradoxus in Tilapia RAS wastewater, and Variovoras spp. in Clarias RAS wastewater (Table 2). Pseudomonas spp. generally are important microorganisms that can promote plant growth as well as producing antimicrobial substances that control plant pathogens $[18,20]$. Pseudomonas veronii specifically has high bioremediation potential and is found in both soil and water environments [44]. Vaiovorax paradoxus and other Variovoras species also have known ability to promote plant growth [45].

Enzyme production is one of the modes of action through which microorganisms combat pathogen attack
[20]. In aquaculture, probiotic microbial taxa such as Actinobacteria, Proteobacteria and Bacteroidetes release various enzymes, such as proteases, chitinases, glucanases, amylases, cellulases, and phosphatases that break down corresponding nutritional components in their substrates [46]. Results of this study indicate that most of the strains isolated from the Tilapia system produce proteases, phosphatases, cellulases and siderophores (Table 2). Pseudomonas veronii isolated from Tilapia RAS wastewater (Isolate 4) exhibited ability to produce all of these enzymes. Pseudomonas fluorescens isolates from Clarias RAS tank water (Isolate 6) and Tilapia RAS wastewater (Isolate 3) could also produce most of the enzymes. Pseudomonas spp. isolated from both RAS systems are well-known for producing siderophores in plant roots that improve the availability of iron by aiding its uptake by plant roots [47]. Thus, the isolates in our study may be good candidates for use in aquaponic systems to increase the availability of phosphorous and iron for plant growth.

In vitro investigations of the antagonistic abilities of the isolated strains highlighted differences in their inhibitory effects on the growth of pathogens. Pseudomonas fluorescens (Isolate 6), Pseudomonas fluorescens (Isolate 3) and Pseudomonas veronii (Isolate 4) suppressed growth of the root pathogen Phytophthora cactorum more than the other strains (Fig. 14). This difference may be due to differences in cellulase production by these strains, which not only breaks down a component in the feed, but can also break down cell walls of pathogens such as $P$. cactorum. However, in vivo antagonistic effects are needed in aquaponics for these results to have practical applicability. Our detached leaf assay provides strong evidence of the antagonistic potential of P. veronii (Isolate 4) and P. fluorescens (Isolate 6) against $P$. cactorum (Fig. 15).

\section{Conclusions}

The current study has contributed new knowledge concerning the role of microbial tools in commercially based recirculated aquaculture systems (RAS) as promoters of plant growth and suppressors of disease. This knowledge strengthens the potential application of RAS as a part of aquaponic systems, which currently face challenges regarding plant nutrients and pathogens. The assemblages of microbial taxa at the level of phyla and genera both in Tilapia and Clarias RAS suggest the suitability of these systems to be used in aquaponic cultivation. However, in terms of promoting plant growth, plant protection and biodegradation, the characteristics of the richness and composition of the microbial communities in the Tilapia system make it the better choice for application in aquaponic systems. The commercial Clarias RAS could also be applied in aquaponic systems, 
but principally from a probiotics perspective due to the dominance of Actinobacteria in this system. Pseudomonas spp. from both Tilapia tank water and waste samples, and Clarias wastes, are good candidates with the potential to produce extracellular enzymes that enhance nutrient uptake. Although the results suggest considerable potential for using microbial communities to manage and control certain aspects of aquaponic systems, our findings need to be strengthened with in vivo studies to explore further the inhibition of plant pathogens and positive effects on plant nutrition. Risks arising from the presence of pathogens also need further investigation. However, our results can still be used as a foundation for the design of aquaponic systems populated with either Tilapia or Clarias. Still, these results need further investigations considering the microbial patterns in the RAS of Tilapia and Clarias in relation to the abiotic and biotic factors in the system.

\section{Materials \& Methods Sample collection}

Two commercial warm and fresh water RAS populated with Tilapia (Oreochromis niloticus) or Clarias (Clarias gariepinus) as the fish species and no aquaponic connection were used as the experimental units. The RAS of Tilapia consisted of a water tank of $70 \mathrm{~m}^{3}$ and of $150 \mathrm{~m}^{3}$ of the Clarias system. A filtration unite is connected the system including a big biofilter and a Degas column for the removal of nitrogen and carbon dioxide and addition of oxygen to the system. Three independent replicates (each $5 \mathrm{~L}$ water samples) were collected at two different sites, viz. from the fish water tanks and from the wastewater where the fish faeces were accumulated. Both RAS with each respective fish type were similarly sampled. The collection site was considered as a treatment. Thus, in total, three fish water samples (biological replicates) and three wastewater samples (biological replicates) were randomly collected from the Tilapia and Clarias systems respectively. The samples were then transferred to the laboratory for subsequent microbial analyses.

\section{Viable count and microbial enumeration}

The viable count method was used to quantify the microbiota in each treatment. Dilution series and enumeration on selective agar media were applied [48]. From this dilution stock, $200 \mu \mathrm{L}$ aliquots were spread, in triplicate, on the following media: (i) $0.1 \%$ Tryptic soya agar (TSA, DIFCO 0369-17-6) complemented with cycloheximide $(100 \mu \mathrm{L} \mathrm{mL}-1)$ to enumerate the general bacterial flora; (ii) $0.5 \%$ malt extract agar (MA, DIFCO 0186-17-7) to enumerate the general fungal flora; and (iii) King Agar B (KB) with cycloheximide $(100 \mu \mathrm{g}$ mL-1) to enumerate the fluorescent pseudomonads. The MA plates were incubated at room temperature for seven days and the TSA and KB plates were incubated for $24 \mathrm{~h}$ at $25{ }^{\circ} \mathrm{C}$.

\section{Microbial community analyses Samples preparation}

The total microbiome analyses started by sterile filtration of $1 \mathrm{~L}$ of the collected samples through $0.2 \mu \mathrm{m}$ filters using bottle-top vacuum filtration systems, PES (WVR- Sweden, 514-0332). The filtration unit filter was then transferred to a $50 \mathrm{~mL}$ tube, washed with 50 $\mathrm{mL}$ sterile autoclaved water, followed by vigorous vortexing for $2 \mathrm{~min}$. The collected material was then centrifuged at $5000 \mathrm{rpm}$ for $10 \mathrm{~min}$ and the pellets were stored at $-80{ }^{\circ} \mathrm{C}$.

\section{DNA extraction}

The DNA extraction was performed using Enzymo DNA preparation kit (D 4300, Sigma Aldrich) following the manufacturer's recommendations.

\section{Illumina sequencing}

The bacterial and fungal communities were sequenced with an Illumina MiSeq $(2 \times 300 \mathrm{bp})$ at LGC Genomics GmbH (Berlin, Germany) [49] using Illumina bcl2fastq 2.17.1.14 software. The bacterial $16 \mathrm{~S}$ ribosomal gene was targeted using the forward primer $341 \mathrm{~F}\left(5^{\prime}\right.$-CCTA CGGGNGGCWGCAG-3') and the reverse primer 785R (5'-GACTACHVGGGTATCTAATCC-3'). The fungal forward primer ITS7F ( $5^{\prime}$-GTG ART CAT CGA ATCT TTG GTT G-3') and the reverse primer $\left(5^{\prime}\right.$-TCC TCC GCT TAT TGA TAT GC-3') were used to target the ITS2 region for fungal assessment. Data pre-processing and OTU picking from amplicons were performed using MOTHUR pipelines (version 1.35.1). Reads with a final length of $<100$ bases were discarded and primer, barcode sequences as well as chimeras were removed. For taxonomical classification, alignment against $16 \mathrm{~S}$ Mothur-Silva SEED r119 reference was performed and sequences from other domains of life were removed. Assignment of operational taxonomic unites, OUTs, was performed at the $97 \%$ identity level using the cluster split method. The fast Tree method was used to generate the phylogenetic trees for $16 \mathrm{~S}$ and ITS, respectively.

\section{Microbial activities \\ Bacterial pure cultures}

For each treatment, two single colonies from the TSA plates and two from the $\mathrm{KB}$ plates were selected and transferred to be grown on broth media of tryptic soya broth (TSB) and King B broth (KBB), respectively. One loopful of culture was inoculated into $15 \mathrm{~mL}$ of the broth media and incubated at $25^{\circ} \mathrm{C}$ with shaking (140 rpm) for $24 \mathrm{~h}$. Bacterial DNA was extracted using the Quick-DNA Bacterial Microprep Kit according to 
the manufacturer's recommendations (Zymo Research, USA). The DNA yield and integrity was assessed using a NanoDrop Micro Photometer (NanoDrop Technologies, UK), and agarose gel electrophoresis, respectively. The 16s rRNA region of all bacterial isolates was PCR amplified individually with the universal primer pairs, $27 \mathrm{~F}$ (5'AGAGTTTGATCMTGGCTCAG-3') and 907R (5'CCGTCAATTCMTTTRAGTTT-3') [50]. PCRs were performed using ten ng of DNA with the following temperature parameters: initial denaturation step at $94{ }^{\circ} \mathrm{C}$ for $3 \mathrm{~min}$, followed by 35 cycles at $94{ }^{\circ} \mathrm{C}$ for $45 \mathrm{~s}$, $50{ }^{\circ} \mathrm{C}$ for $30 \mathrm{~s}$, and $72{ }^{\circ} \mathrm{C}$ for $30 \mathrm{~s}$, followed by a final extension step of $72{ }^{\circ} \mathrm{C}$ for $5 \mathrm{~min}$. The PCR products were purified using the Qiagen QIAquick PCR Purification Kit (Qiagen, UK). Sanger sequencing for species identification was carried out at the GATC biotech AG sequencing facility (Germany) using $27 \mathrm{~F}$ and 907R primers. DNA star software was used (DNASTAR, USA) to analyze and edit nucleotide sequences obtained from the sequencing platform manually. Resulting sequences with $16 \mathrm{~s}$ region were searched for matching hits against the National Center for Biotechnology Information (NCBI) GenBank non-redundant nucleotide database (BLASTn; [51]). Search hits to sequences from records in the database were evaluated for coverage and identity and the best matched NCBI accession was recorded.

\section{Enzyme activities}

Functional characters of the isolates were assessed by assaying their enzymatic activities. The isolated bacterial colonies were screened for amylase, protease, phosphatase, siderophores and cellulase production on functional media in plate assays [52]. The M9 Minimal Salts medium (VWR, Sweden) was used as a base medium. For amylase assays, the isolates were inoculated on M9 media amended with $1 \%(\mathrm{w} / \mathrm{v})$ starch and incubated for $24-72 \mathrm{~h}$ at $20 \pm 2{ }^{\circ} \mathrm{C}$. After incubation, the plates were flooded with Lugol iodine, and a zone of clearance around colonies against the resulting dark background was taken as an indication of amylase production.

For assessing protease activity, the isolates were inoculated on M9 plates amended with skimmed milk $(20 \mathrm{~mL}$ $\mathrm{L}^{-1}$ ), incubated for $24-72 \mathrm{~h}$ at $20 \pm 2{ }^{\circ} \mathrm{C}$, and formation of a halo around the colonies indicated protease production. The same incubation conditions and indicative criteria were used for assessing cellulase production. For this, the M9 plates amended with (1\%) carboxymethyl cellulose were used, which were flooded with Congo Red solution $(0.2 \% \mathrm{w} / \mathrm{v})$ for $30 \mathrm{~min}$ then washed with $1 \mathrm{M}$ $\mathrm{NaCl}$ solution.

For phosphatase activity assays, tryptose phosphate agar plates supplemented with Methyl Green (0.05 mg $\mathrm{mL}^{-1}$ ) were used. The plates were incubated for 5 days at $20 \pm 2{ }^{0}$ C. Development of green coloration, after incubation, indicated positive phosphatase activity. Siderophores production was also assessed, using Chromazurol $\mathrm{S}$ agar plates inoculated with bacterial isolates and incubated for three days at $20 \pm 2{ }^{\circ} \mathrm{C}$. The formation of an orange halo around the colonies indicated siderophores production.

\section{In vitro antagonistic assay}

The bacterial strains isolated were screened for antagonistic potential towards the oomycete/fungal pathogens Phytophthora cactorum and Verticillium dahlia. The assay was performed on cornmeal agar (CMA) plate agar plates with the mycelial plug $(1 \times 1 \mathrm{~cm})$ of the test pathogen placed in the centre followed by streaking test bacterial isolate three $\mathrm{cm}$ apart on either side of the pathogen plug and monitored for ten days at $20{ }^{\circ} \mathrm{C}$. Controls constitute only the test pathogens. The experiments were repeated thrice with three replicates for each independent experiments. The radial growth of the pathogen growth towards test bacteria was measured and the Growth Inhibition Percentage (GIP) was calculated according to the following formula:

$$
(\%)=(R C-R T) / R C \times 100 .
$$

where $\mathrm{RC}$ constitutes radial growth of the pathogen in the control plate $(\mathrm{cm})$ and RT is the radial growth of the pathogen $(\mathrm{cm})$ in the treated plate [53].

\section{Detached leaf assay (DLA)}

The antagonistic potential of bacterial isolates towards the strawberry pathogen $P$. cactorum was tested in a detached leaf assay. The best performing bacterial isolates with the highest antagonistic activity from the in vitro studies were selected for the DLA assay. The bacteria were cultured overnight on Tryptic Soy Broth media at $28{ }^{\circ} \mathrm{C}$ and pelleted. The pellet was washed and resuspended in distilled water, followed by density measurement and adjustment to OD 0.1 at $600 \mathrm{~nm}$.

For zoospore production, $P$. cactorum isolate RV4 was cultured as described [54]. For sporangia formation, the agar plugs from the outer edges of freshly growing mycelium colonies were subjected to dark conditions on V8 media for three days followed by treatment with autoclaved soil extract solution under light conditions for $48 \mathrm{~h}$. The sporangial suspensions obtained were subjected to cold treatment at $8{ }^{\circ} \mathrm{C}$ to release the zoospores over an average $2-3 \mathrm{~h}$ period depending on the zoospore's release efficiency. The zoospore inoculum was collected and counted using a haemocytometer to adjust inoculum to 20000 zoospores per $\mathrm{mL}$.

Young strawberry leaflets (cv. Sonata) grown in controlled conditions were used to assess disease development. The leaves were placed adaxial side facing up on 
moist paper in clear plastic containers and inoculated with a mixture of zoospore and bacterial suspension with approximately 20,000 zoospores and OD $=0.1$ bacterial suspension in a $20 \mu \mathrm{l}$ droplet on either side of the leaf.

midrib. The controls constituted either sterile water or pathogen only. The plastic containers were tightly sealed and placed at $20{ }^{\circ} \mathrm{C}$ with $16 \mathrm{~h}$ photoperiod. Pathogenicity phenotypes were photographed and assessed at 4 days post-inoculation (DPI) using the image-processing program ImageJ. Each independent experiment was evaluated with six replicates and the experiments were repeated thrice.

\section{Statistical analyses}

All statistical analyses were performed within Microbiome Analyst v1.0 [55]. OTUs were pre-filtered before conducting any statistical analysis by retaining those present in at least two samples. The data were normalized using the total sum scaling method (counts per million normalization) to address variability in sampling depth. Alpha diversity profiling was conducted using Shannon and Chaol diversity indices and statistical significance testing using analysis of variance (ANOVA). To examine differences between the different groups in community compositions, beta diversity was calculated using unweighted Unifrac Distance and statistical comparisons performed with ANalysis of SIMilarities (ANOSIM). Patterns of sample dissimilarity were visualized using Principal Coordinate Analysis (PCoA) plots. In addition, hierarchical clustering and heatmaps were constructed using the Ward clustering algorithm and Euclidean distance measure to examine the robustness of sample clustering and relative abundances. The results from the microbial enumeration were log-transformed to meet the assumptions of homogeneity and normality. The significance effect of treatment was tested by ANOVA followed by Tukey's multiple comparison test $(\mathrm{p}<0.05)$ using Minitab v16. To explore how top taxa differed between the different cultivation/waste types, classical univariate statistical comparisons were inferred using t-test/ANOVA method with an adjusted p-value cutoff of 0.05 .

\section{Acknowledgements}

Richertska Stiftelsen funded this research at https://www.sweco.se/om-oss/ priser-och-stipendier/richterska-stiftelsen/, which is greatly acknowledged. The staff at the fish company where the samples have been collected are also acknowledged for their help.

\section{Authors' contributions}

Sammar Khalil: Funding acquisition; design, and performance of the experiments with respect to microbial assessments and enzyme activities; writing - original draft preparation. Preeti Panda: Metagenomic analyses; writing - review and editing the manuscript. Ramesh Vetukuri: design, and performance of the experiments, strain identification; in vitro investigations; writing - review and editing the manuscript. Farideh Ghadamgahi: in vitro and DLA investigations; writing - review and editing the manuscript. AnnaKarin Rosberg: DNA extraction, comments on the manuscript. The author(s) read and approved the final manuscript.

\section{Authors' information}

Not applicable

\section{Funding}

The project was funded by Richertska Stiftelsen (https://www.sweco.se/omoss/priser-och-stipendier/richterska-stiftelsen/ grant 218-00425). The work of Ramesh Vetukuri was supported by FORMAS, The Swedish Research Council (grants 2019-01316, 2019-04270) and NKJ-SNS -Dialogue Biocontrol network (NKJ-SNS 06) andDepartment of Plant Breeding, SLU. Open Access funding provided by Swedish University of Agricultural Sciences.

\section{Availability of data and materials}

The sequenced data were submitted to Genbank database and got the submission ID (SUB8541601) and the bioProject ID (PRJNA702651). The project information are accessible with the following link: https://www.ncbi. nlm.nih.gov/sra/PRJNA702651

\section{Declarations}

Ethics approval and consent to participate

No live fish were handled during this study.

Consent for publication

Not applicable.

Competing interests

The authors declare no competing interests.

\section{Author details}

${ }^{1}$ Department of Biosystems and Technology, Swedish University of Agricultural Sciences, Box 103, 23053 Alnarp, Sweden. Plant and Food Research, Plant Protection, Lincoln, New Zealand. ${ }^{3}$ Department of Plant Breeding, Swedish University of Agricultural Sciences, Box 102, 23053 Alnarp, Sweden.

Received: 8 February 2021 Accepted: 25 June 2021

Published online: 05 July 2021

\section{References}

1. Kummu M, De Moel H, Porkka M, Siebert S, Varis O, Ward P J. Lost food, wasted resources: Global food supply chain losses and their impacts on freshwater, cropland, and fertilizer use. Sci. Total Environ. 2012; 438: 477489.

2. The State of Food and Agriculture: Leveraging Food Systems for Inclusive Rural Transformation; Food and Agriculture Organization of the United Nations: Roma, Italy, 2017; ISBN 9251098735.

3. Ga, U.N. Transforming our World: The 2030 Agenda for Sustainable Development; Division for Sustainable Development Goals: 2015; New York, NY, USA.

4. FAO (Food and Agriculture Organization of the United Nations). The State of World Fisheries and Aquaculture. 2016; Available online: http://www.fao. org/3/a-i5555e.pdf.

5. Martins CIM, Eding EH, Verdegem MCJ, Heinsbroek LTN, Schneider O, Blancheton JP, Roque d'Orbcastel E, Verreth JAJ. New developments in recirculating aquaculture systems in Europe: a perspective on environmental sustainability. Aquacul. Engin. 2010: 43 (3): 83-93.

6. Goddek S, Delaide B, Mankasingh U, Ragnarsdottir KV, Jijakli H, Thorarinsdottir R. Challenges of sustainable and commercial aquaponics. Sustain. 2015; 7: 199-4224. https://doi.org/10.3390/su7044199

7. Endut A, Jusoh A, Ali N, WanNik WB, Hassan AA. Study on the optimal hydraulic loading rate and plant ratios in recirculation aquaponic system. Bioresour Technol. 2010: 10: 1511-1517

8. Yildiz HY, Robaina L, Pirhonen J, Mente E. Fish Welfare in Aquaponic Systems: Its Relation to Water Quality with an Emphasis on Feed and Faeces_A Review. Water. 2017; 9: 13, doi:https://doi.org/10.3390/w9010013 
9. Domínguez D, Parisi G, Monsees H, Kloas W, Wuertz S. Decoupled systems on trial: eliminating bottlenecks to improve aquaponic processes. PLoS One. 2017; 12(9): https://doi.org/10.1371/journal.pone.0183056

10. Postma J, van Os E, Bonants PJM. Ch 10 - pathogen detection and management strategies in soilless plant growing system. In: Soilless culture: theory and practice. Elsevier B.V., Amsterdam. 2008; 425-457. https://doi. org/10.1016/B978-0-444-52975-6.50012-5

11. Alhussaen K. Pythium and Phytophthora associated with root disease of hydroponic lettuce. University of Technologie Sydney Faculty of Science 2006, https://opus.lib.uts.edu.au/handle/10453/ 36864

12. Fujiwara K, Aoyama C, Takano M, Shinohara M. Suppression of Ralstonia solanacearum bacterial wilt disease by an organic hydroponic system. J Gen Plant Pathol. 2012; https://doi.org/10. 1007/s10327-012-0371-0.

13. Ito S, Takikawa Y, Tairako K. Black rot of pak-choi in hydroponics caused by Xanthomonas campestris pv. Campestris. Japan. J. of phytopath. 2003; DOI: https://doi.org/10.3186/JJPHYTOPATH.69.407.

14. Calvo-bado LA, Pettitt TR, Parsons N, Petch GM, Morgan JAW, Whipps JM. Spatial and Temporal Analysis of the Microbial Community in Slow Sand Filters Used for Treating Horticultural Irrigation Water. Appl. Envir. Microbiol. 2003; 69: 2116-2125.

15. Chatterton S, Sutton JC, Boland GJ. Timing Pseudomonas chlororaphis applications to control Pythium aphanidermatum, Pythium dissotocum, and root rot in hydroponic peppers. Biol Cont. 2004; 30: 360-373.

16. Cherif $M$, Tirilly $Y$, Belanger RR. Effect of oxygen concentration on plant growth, lipid peroxidation, and receptivity of tomato roots to Pythium under hydroponic conditions. Eur J Plant Pathol. 1997; 103: 255-264

17. Ehret DL, Alsanius B, Wohanka W, Menzies JG, Utkhede R. Disinfestation of recirculating nutrient solutions in greenhouse horticulture. Agronomie 2001; 21: $323-339$

18. Renault D, Déniel F, Benizri E, Sohier D, Barbier G, Rey P. Characterization of Bacillus and Pseudomonas strains with suppressive traits isolated from tomato hydroponic-slow filtration unit. Can J Microbiol. 2007; 53: 784-797.

19. Renault D, Vallance J, Déniel F, Wery N, Godon JJ, Barbier G, Rey P. Diversity of bacterial communities that colonize the filter units used for controlling plant pathogens in soilless cultures. Microb Ecol. 2012; 63:170-187.

20. Mazzola M. Assessment and management of soil microbial community structure for disease suppression. An. Rev. Phytopath. 2004; 42: 35-59.

21. Zeng Q, Tian X, Wang L. Genetic adaptation of microbial populations present in high-intensity catfish production systems with therapeutic oxytetracycline treatment. Sci Rep. 2017;7:1-13.

22. Eck M, Sare AR, Massart S, Schmautz Z, Junge R, Smits THM, Jijakli MH. Exploring Bacterial Communities in Aquaponic Systems. Water. 2019; 11: 260, doi:https://doi.org/10.3390/w11020260.

23. Schmautz Z, Graber A, Jaenicke S, Goesmann A, Junge R, Smits THM. Microbial diversity in different compartments of an aquaponics system. Arch of Microbiol. 2016b; 613-620.

24. Eissa N, Abou El-Ghiet EN. Efficacy of Pseudomonas fluorescens as biological control agents against Aeromonas hydrophila infection in Oreochromis niloticus. World J. Fish Mar. Sci. 2012; 3: 564-569.

25. Jimoh WA, Sulyman T, Taiwo AT. Microbial load and diversity in the gastrointestinal tract of cultured Nile tilapia (Oreochromis niloticus) and hybrid catfish (Clarias gariepinus $q \times$ Heterobranchus bidorsalis ${ }^{\text {) }}$ ) in Ilorin Metropolis, Nigeria. Int. J. Aquatic Biol, 2019; 7(5): 271-279, DOl: https://doi. org/10.22034/ijab.v7i5.672

26. Minich JJ, Zhu O, Xu ZZ, Amnon A, Ngochera M, Simwaka M, Allen EE, Zidana $\mathrm{H}$, Knight $\mathrm{R}$. Microbial effects of livestock manure fertilization on freshwater aquaculture ponds rearing Tilapia (Oreochromis shiranus) and North African catfish (Clarias gariepinus). Microbiol Open, 2018; https://doi. org/10.1002/mbo3.716

27. Giatsis C, Sipkema D, Smidt H, Heilig H, Benvenuti G, Verreth J, Verdegem M The impact of rearing environment on the development of gut microbiota in tilapia larvae. Scientific Reports, 2015; 5: 18206

28. Liu S, Ren H, Shen L, Lou L, Tian G, Zheng P, Hu B. pH levels drive bacterial community structure in sediments of the Qiantang River as determined by 454 pyrosequencing. Front Microbiol 2015; 6: 285.

29. Campbell BJ, Kirchman DL. Bacterial diversity, community structure and potential growth rates along an estuarine salinity gradient. SME J. 2013; 7: 210-220.

30. Schreier HJ, Mirzoyan N, Saito K. Microbial diversity of biological filters in recirculating aquaculture systems. Cur. Opin. Biotech. 2010; 21: 318-325.
31. Garcia JC, Ketover RDJ, Loh AN, Parsons ML, Urakawa H. Influence of freshwater discharge on the microbial degradation processes of dissolved organic nitrogen in a subtropical estuary. Antonie Van Leeuw. 2015; 107: 613-632.

32. Das $S$, Ward $L R$, Burke $S$. Prospects of using marine actinobacteria as probiotics in aquaculture. Appl Microbiol Biotechnol 2008; 81:419-429 DOI https://doi.org/10.1007/s00253-008-1731-8.

33. Jami M, Ghanbari M, Kneifel W, Domig KJ. Phylogenetic diversity and biological activity of culturable Actinobacteria isolated from freshwater fish gut microbiota. Microbiol. Res. 2015: 175: 6-15.

34. Sanchez FA, Vivian-Rogers VR, Urakawa H. Tilapia recirculating aquaculture systems as a source of plant growth promoting bacteria. Aquacul Res. 2019; 50: 2054-2065, DOl: https://doi.org/10.1111/are.14072.

35. Sirakov I, Lutz M, Graber A, Mathis A, Staykov Y, Smits THM, Junge R. Potential for combined biocontrol activity against fungal fish and plant pathogens by bacterial isolates from a model aquaponic system. Water. 2016; 8:518.

36. Guo X, Miao Y, Wu B, Ye L, Yu H, Liu S, Zhang X-x. Correlation between microbial community structure and biofouling as determined by analysis of microbial community dynamics. Bioresource Techn. 2015; 197: 99-105.

37. Albertsen M, Mcllroy SJ, Stokholm-Bjerregaard M, Karst SM, Nielsen P. Candidatus Propionivibrio aalborgensis": A Novel Glycogen Accumulating Organism Abundant in Full-Scale Enhanced Biological Phosphorus Removal Plants. Front. in Microb. 2017;1033. doi: https://doi.org/10.3389/fmicb.2016. 01033.

38. Shu D, He Y, Yue H, Wangd O. Microbial structures and community functions of anaerobic sludge in six full-scale wastewater treatment plants as revealed by 454 high-throughput pyrosequencing. Bioresource Techn. 2015; 186: 163-172.

39. Martins P, Cleary DFR, Pires A CC, Rodrigues AM, Quintino V, Calado R, Gomes NCM Molecular Analysis of Bacterial Communities and Detection of Potential Pathogens in a Recirculating Aquaculture System for Scophthalmus maximus and Solea senegalensis. Plos One. 2013; 8 (11): e80847.

40. Tagawa M, Tamaki H, Manome A, Koyama O, Kamagata Y. Isolation and characterization of antagonistic fungi against potato scab pathogens from potato field soils. FEMS Microbiol Lett. 2010; 305: 136-142.

41. Vinalea F, Sivasithamparamb K, Ghisalbertic EL, Marraa R, Wooa SL, Lorito M Trichoderma-plant-pathogen interactions. Soil Biol. \& Bioch. 2008; 40: 1-10.

42. Bailey BA, Apel-Birkhold PC, Akingbe O O, Ryan J L, O'Neill NR, Anderson JD, Nep1 Protein from Fusarium oxysporum Enhances Biological Control of Opium Poppy by Pleospora papaveracea. Phytopathol. 2000; 90 (8): 812-818.

43. Auer S, Ludwig-Müller J. Biological control of clubroot (Plasmodiophora brassicae) by the endophytic fungus Acremonium alternatum. J. Endocyt. and Cell Res. 2015; 26: 43-49.

44. Vullo DL, Ceretti HM, Daniel MA, Ramı́rez SAM, Zalts A. Cadmium, zinc and copper biosorption mediated by Pseudomonas veronii $2 \mathrm{E}$. Bioresour Technol 2008; 99: 5574-5581

45. Han JI, Choi HK, Lee SW, Orwin PM, Kim J, LaRoe SL, Kim TG, O'Neil J, Leadbetter JR, Lee SY, Hur C-G, Spain JC, Ovchinnikova G, Goodwin L, Han C. Complete Genome Sequence of the Metabolically Versatile Plant GrowthPromoting Endophyte Variovorax paradoxus S110. J. of bacterial. 2011; 193 (5): 1183-1190, doi:https://doi.org/10.1128/JB.00925-10.

46. Dean RA, Timberlake WE. Production of Cell Wall-Degrading Enzymes by Aspergillus nidulans: A Model System for Fungal Pathogenesis of Plants. The Plant Cell 1989; 1: 265-273.

47. Djibaoui R, Bensoltane A. Effect of iron and growth inhibitors on siderophores production by Pseudomonas fluorescens. Afric J. Biotechnol. 2005; 4 (7): 697-702

48. Khalil S, Alsanius BW. Dynamics of the indigenous microflora inhabiting the root zone and the nutrient solution of tomato in a commercial closed greenhouse system. Gartenbauwissen. 2001;66:188-98.

49. Darlison J, Mogren L, Rosberg A, Grudén M, Minet A, Line C, Mieli M, Bengtsson T. Leaf mineral content govern microbial community structure in the phyllosphere of spinach (Spinacia oleracea) and rocket (Diplotaxis tenuifolia). Scien. Total. Envir. 2019; 675, DOl: https://doi.org/10.1016/j.scitotenv.2019.04.254

50. Morales SE, Holben WE. Empirical testing of $16 \mathrm{~S}$ rRNA gene PCR primer pairs reveals variance in target specificity and efficacy not suggested by in silico analysis. Appl. Envir. Microbiol. 2009; 75: 2677-2683.

51. Altschul SF, Madden TL, Schäffer A. et al. Gapped BLAST and PS I-BLAST: a new generation of protein database search programs. Nucl. Acid. Res. 1997 25: 3389-3402. doi: https://doi.org/10.1093/nar/25.17.3389 
52. Choudhary DK, Agarwal P K, Johri BN. Characterization of functional activity in composted casing amendments used in cultivation of Agaricus bisporus (Lange) Imbach. Ind. J. of Biotech 2009; 8(1): 97-109.

53. Rahman MA, Begum M F, Alam M F. Screening of Trichoderma Isolates as a Biological Control Agent against Ceratocystis paradoxa Causing Pineapple Disease of Sugarcane. Mycobiol. 2009; 37(4): 277. doi: https://doi.org/10.44 89/MYCO.2009.37.4.277.

54. Vetukuri RR, Tripathy S, Malar CM, Panda A, Kushwaha SK, Chawade A, Andreasson E, Grenville-Briggs LG, Whisson SC. Draft Genome Sequence for the Tree Pathogen Phytophthora plurivora, Gen. Biol. and Evol. 2018; 10 (9): 2432-2442, https://doi.org/10.1093/gbe/evy162

55. Dhariwal A, Chong J, Habib S, King IL, Agellon LB, Xia J. Microbiome Analyst: a web-based tool for comprehensive statistical, visual and metaanalysis of microbiome data. Nucleic Acids Res. 2017;45:W180eW188. https://doi.org/1 0.1093/nar/gkx295

\section{Publisher's Note}

Springer Nature remains neutral with regard to jurisdictional claims in published maps and institutional affiliations.

Ready to submit your research? Choose BMC and benefit from:

- fast, convenient online submission

- thorough peer review by experienced researchers in your field

- rapid publication on acceptance

- support for research data, including large and complex data types

- gold Open Access which fosters wider collaboration and increased citations

- maximum visibility for your research: over $100 \mathrm{M}$ website views per year

At BMC, research is always in progress.

Learn more biomedcentral.com/submissions 